\title{
各種の高張力異形鉄筋を用いた鉄筋コンクリート 大型ばりの疲労に関する研究
}

\author{
FATIQUE BEHAVIOR OF REINFORCED CONCRETE \\ BEAMS WITH HIGH STRENGTH DEFORMED BARS
}

国 分 正 扸*・多田美 朝** ・立花一郎** - 松 本 嘉司***

By Masatane Kokubu, Yoshiaki Tada, Ichiro Tachibana and Yoshiji Matsumoto

\section{1. 緒論}

最近各種の高張力異形鉄筋が開発され, また鉄筋およ びコンクリートの品質の向上とともに，これらの異形鉄 筋を用いた鉄筋コンクリート桁橋の経済スパンも急激に 増大している。しかし橋梁に鉄筋コンクリート桁を用い る場合には活荷重がくり返し作用するので, 静荷重によ る曲げ性状のほかに, その疲労性状が問題となってく る。従来の鉄笔コンクリート構造物ではコンクリートの 許容応力度を $80 \mathrm{~kg} / \mathrm{cm}^{2}$ 以下に, 鉄筋の許容応力度は $1400 \sim 1600 \mathrm{~kg} / \mathrm{cm}^{2}$ 以下にとって設計していたので, その疲労性状についての問題点は比較的少なかったが， 最近はそれらの許容応力度を高くと って設計しょうとする気運があり， そのために品質のよいコンクリート と高張力異形鉄筋とを用いた鉄筋コ ンクリートばりの疲労性状を明らか にすることが必要になってきたので ある。

本研究は八幡製鉄, 富士製鉄, 日 本鋼管，川崎製鉄，神戸製鋼，住友 金属の 6 社で製造, 市販されている 丸鋼，各種の異形鉄筋および数種の 試作品と圧縮強度が $300 \sim 400 \mathrm{~kg} /$ $\mathrm{cm}^{2}$ のコンクリートを用いて, はり 高さ $50 \mathrm{~cm}$, 全長 $5 \mathrm{~m}$ の T形断面の 大型試験ばりをつくり,これに静荷 重および疲労荷重を加えて, 主とし てその曲げ疲労性状について考察を 加えたものである。実験の数は限定 されているが，わが国で市販されて いる代表的な異形鉄筋を用いた鉄笳 コンクリートばりの疲労性状について一応の結論は得ら れたものと信じている。

\footnotetext{
* 正会員 工博 東京大学教授 工学部土木工学科

** 正会員国鉄鉄道技術研究所

*** 正会員 工博 国鉄構造物設計事務所
}

本研究は土木学会異形鉄筋実験研究小委員会の実験研 究費によって行なわれたものであって, 試験の実施につ いてご協力を戴いた東京大学 岡村 甫氏および東京大学 コンクリート研究室の関係者, 鉄道技術研究所構造物研 究室の関係者および試験結果の解析にご協力を載いた国 鉄構造物設計事務所安本修一氏などの方々に厚く謝意を 表する次第である。

\section{2. 静荷重試験および疲労荷重試験}

\section{（1）試験ばり}

試験ばりは図一1に示すようにスパン $4.6 \mathrm{~m}$, 全長 5 $\mathrm{m}$, はり高さ $50 \mathrm{~cm}$, 腹部の幅 $20 \mathrm{~cm}$, フランジ幅 $40 \mathrm{~cm}$

図一1 試 験 ばり（○印は鉄筋のひずみの測定点を示す）

I 型

II 型

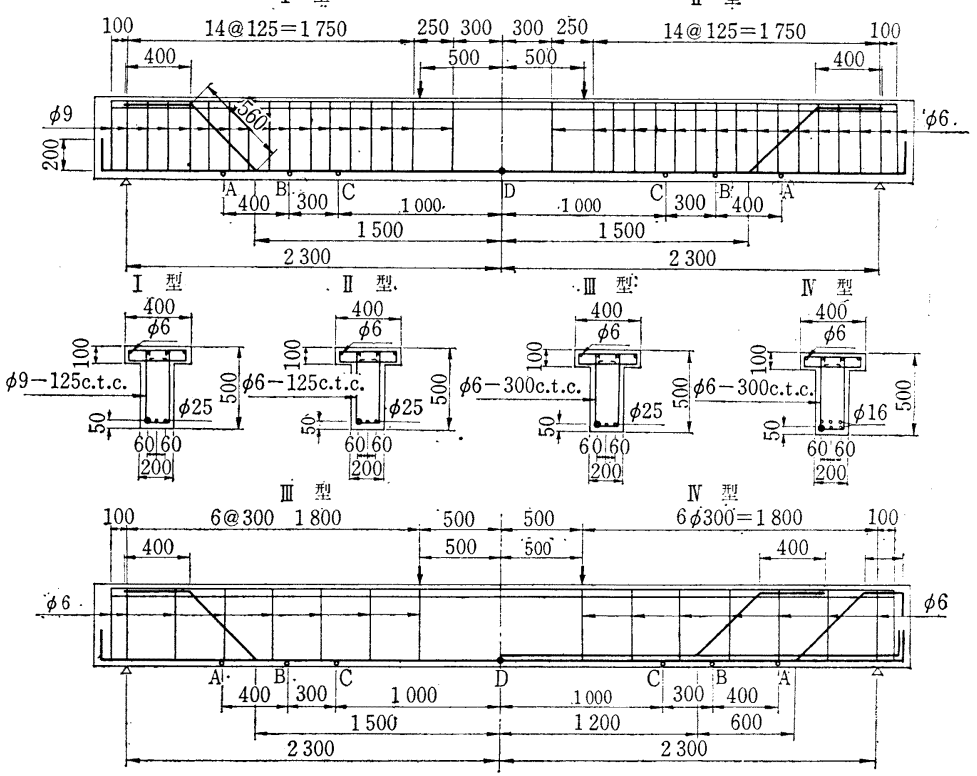

フランジ厚さ $10 \mathrm{~cm}$ の $\mathrm{T}$ 形断面のはりで，引張鉄筋お よびせん断補強鉄筋量を変えて製作した。引張鉄筋は 1 種類を除いてすべて直径 $25 \mathrm{~mm}$ の鉄筋 3 本に一定し, せん断補強はスターラップ の配筋によって 図一1 に示 すように I 型, II 型, III型の 3 種に定めた。試験ばりの 
らちの 1 種類は引張鉄筋の直径の影響を見る目的で引張 鉄筋を直径 $16 \mathrm{~mm} 6$ 本とし, そのせん断補強鉄筋は図 -1 に示すようにスターラップ の配置を III 型と同一に し折曲鉄筋のみ変えた IV 型とした。表一1 はこのせん断 補強鉄筋を比較して示したものである。

この試験ばりはオリエンタル コンクリート KK 多摩 工場で製作したが，その際に図一1に示寸位置の鉄筋に ワイヤ ストレィン ゲージを貼って, 防水工でコートし てからコンクリート施工を行なった。

\section{表一1 せん断補強鉄筋}

\begin{tabular}{|c|c|c|c|}
\hline & 大 $夕$ - & プ & 折曲鉄筋 \\
\hline I & 14 (a) 125 & $\phi 9$ & $1-\mathrm{D} \phi 25$ \\
\hline II & $"$ & $\phi 6$ & " \\
\hline III & 6 (a) 300 & $"$ & $"$ \\
\hline IV & " & " & $2-\mathrm{D} \phi 16$ \\
\hline
\end{tabular}

\section{（2）セメント，骨材およびコンクリート}

試験ばりの製作に使用したセメントおよび骨材の試験 結果を示すと 表一2 および 表一3 のようになる。また このコンクリートの示方配合は 表一4 に示すとおり一 種とし, 材令 28 日における 3 個の標準供試体の圧縮強 度の平均值は 表一6, 8 に示すように $300 \sim 400 \mathrm{~kg} / \mathrm{cm}^{2}$ で，コンクリートの施工時の スランプは $5 \sim 6 \mathrm{~cm}$ であ る。またこのコンクリートの試験時における圧縮試験結 果より求めたヤング係数はコンクリートのひずみが 0 $200 \times 10^{6}$ の範囲で約 $3.0 \times 10^{5} \mathrm{~kg} / \mathrm{cm}$ である。

\section{(3) 鉄 筋}

使用した鉄筋は 1 種をのぞいてすべて直径 $25 \mathrm{~mm}$ で， 丸鋼 2 種, 旧 JIS 型の縦リブ横フシ丸型異形鉄筋 3 種, 縦リブ斜フシ丸型異形鉄筋 9 種, 三角断面の異形鉄筋 2 種で, 強度試験結果および化学成分は 表一 5 に示すよう である。写真一1 はこの鉄筋の形状を示したものである。

\section{(4) 試験方法}

試験ばりの曲げ試験は 図一1 に示すようにスパンを $4.6 \mathrm{~m}$ にとり, 集中 2 点荷重を加えて行なった。この試 験機は鉄道技術研究所構造物研究室のローゼンハウゼン 型大型疲労試験機（森試験機製で最大荷重は静的には $2 \times 75 \mathrm{t}$, 動的には $2 \times 50 \mathrm{t}$, 荷重のくり返し速度は 166 500 回/分) である。写真一2 はこの試験装置を示したも のである。

曲げ試験は静荷重試験と, 荷重を増減してくり返し曲 げを加える疲労荷重試験とについて行なった。静荷重試 験を行なったのは表一6に示す 9 本の試験ばりで， 2 点 荷重の合計を $2 \mathrm{t}$ おきに破壊荷重をで上げて試験を行な 、,コンクリートの表面および引張鉄筋のワイヤ ストレ インゲージによるひずみ測定，スパン中央抢よび支承 部のたわみ測定およびコンタクト ゲージによるひびわ れ幅測定を行なった。ワイヤ ストレィン ゲージの測定 にはブラウン管式ひずみ計を用いた。コンタクトゲー ジは試験ばりの腹部下端側面の鉄筋位置に約 $10 \mathrm{~cm}$ 間隔 に貼った鉄片上に設けた標点間の距離を機械的に測定す るもので，これによってその間に成長するひびわれ幅を 測定することができるものである。なおこのひびわれの 成長および破壊状況については肉眼による観測も行なっ た。静荷重試験を行なった試験ばりはすべて引張鉄筋に 3-D ф $25 \mathrm{~mm}$ を用いたもので，そのせん断補強鉄筋は表 一6に示すようにI 型およびII 型である。

疲労荷重試験を行なった試験ばりは全部で 20 本であ る。引張鉄筋に 3-D $\phi 25 \mathrm{~mm}$ を用いた試験ばりの疲労 荷重試験は上記の集中 2 点荷重の合計を $2 \sim 16 \mathrm{t}$ 亿変化: させてまず $10^{6}$ 回くり返し載荷した。実際に市販されて いる鉄筋を用いて製作した試験ばりの大部分がこの荷重 段階で破壊しなかったので，さらに荷重の上限のみ高め

表一2 早強セメントの試験成縝

\begin{tabular}{|c|c|c|c|c|c|c|c|c|c|c|c|c|}
\hline \multirow[b]{2}{*}{ 比 } & \multirow{2}{*}{$\begin{array}{c}\text { ブレ王面積 } \\
\left(\mathrm{cm}^{2} / \mathrm{g}\right)\end{array}$} & \multicolumn{2}{|c|}{ 凝 } & 結 & \multirow[b]{2}{*}{ フロー值 } & \multicolumn{3}{|c|}{ 曲げ強さ $\left(\mathrm{kg} / \mathrm{cm}^{2}\right)$} & \multicolumn{3}{|c|}{ 压樎強さ $\left(\mathrm{kg} / \mathrm{cm}^{2}\right)$} & \multirow[b]{2}{*}{ 安定性 } \\
\hline & & 水 $(\%)^{\text {量 }}$ & 始 ${ }_{(h-m)}$ 発 & $\begin{array}{l}\text { 終 } \\
(\mathrm{h}-\mathrm{m})\end{array}$ & & 3 日 & 7 日 & 28 日 & 3 日 & 7 日 & 28 日 & \\
\hline 3.12 & 4400 & 29.2 & $2-02$ & $2-57$ & 241 & 47.1 & 62.6 & 82.4 & 215 & 332 & 472 & 良 \\
\hline
\end{tabular}

表一3 使用骨材の試験成績

\begin{tabular}{|c|c|c|c|c|c|c|c|c|c|c|c|c|c|c|c|c|c|c|}
\hline & & \multirow[b]{2}{*}{ 地 } & \multicolumn{3}{|c|}{ s. } & $h$ & 通 & 過 & 量 & \multicolumn{3}{|c|}{$(\%)$} & \multirow{2}{*}{$\begin{array}{c}\text { 粗 粒 率 } \\
\text { F.M }\end{array}$} & \multirow[b]{2}{*}{ 比 } & \multirow{2}{*}{$\begin{array}{c}\text { 吸 水 量 } \\
(\%)\end{array}$} & \multirow{2}{*}{$\begin{array}{l}\text { 蛍積重量 } \\
\left(\mathrm{kg} / \mathrm{m}^{3}\right)\end{array}$} & \multirow{2}{*}{\multicolumn{2}{|c|}{$\begin{array}{l}\text { 有機 } \\
\text { 純物 } \\
\text { 試験 }\end{array}$}} \\
\hline & & & $\mathrm{mm}_{30}^{\mathrm{mm}}$ & $\mathrm{mm}_{25}^{\mathrm{mm}}$ & $\mathrm{20}_{20}^{\mathrm{mm}}$ & $\underset{10}{\mathrm{~mm}}$ & ${ }_{5}^{\mathrm{mm}}$ & $\underset{2.5}{\mathrm{~mm}}$ & $\underset{1.2}{\mathrm{~mm}}$ & $\underset{0.6}{\mathrm{~mm}}$ & $\begin{array}{l}\mathrm{mm} \\
0.3\end{array}$ & $\underset{0.15}{\mathrm{~mm}}$ & & & & & & \\
\hline 粗骨材 & 荒 & 川 & 100 & 99 & 25 & 1 & 1 & 1 & 0 & 0 & 0 & 0 & 6.77 & 2.68 & 0.8 & 1631 & 合 & 格 \\
\hline 細骨材 & 荒 & 川 & & & & 100 & 99 & 78 & 55 & 27 & 10 & 1 & 3.30 & 2.63 & 1.0 & 1675 & 合 & 格 \\
\hline
\end{tabular}

表一4コンクリートの示方配合

\begin{tabular}{|c|c|c|c|c|c|c|c|c|c|}
\hline 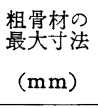 & $\begin{array}{c}\text { スラン プ } \\
\text { の 範 团 } \\
(\mathrm{cm})\end{array}$ & $\begin{array}{c}\text { 空気量の範团 } \\
(\%) \\
(\%)\end{array}$ & $\begin{array}{c}\text { 単位水量 } \\
W \\
(\mathbf{k g})\end{array}$ & $\mid \begin{array}{c}\text { 単位セメント量 } \\
C \\
(\mathrm{~kg})\end{array}$ & $\begin{array}{c}\text { 水セメント比 } \\
w / c \\
(\%)\end{array}$ & $\begin{array}{c}\text { 絶対細骨材率 } \\
s / a \\
(\%) \\
\end{array}$ & $\begin{array}{c}\text { 単位細骨材量 } \\
(\mathrm{kg})\end{array}$ & $\begin{array}{c}\text { 単位粗骨材量 } \\
(\mathrm{kg})\end{array}$ & $\begin{array}{c}\text { AE 剂 量 } \\
\text { Vinsol Resin } \\
\text { (g) }\end{array}$ \\
\hline 25 & $5 \sim 6$ & $3 \sim 4$ & 156.4 & 340 & 46 & 44.5 & 856 & 1069 & 29.1 \\
\hline
\end{tabular}




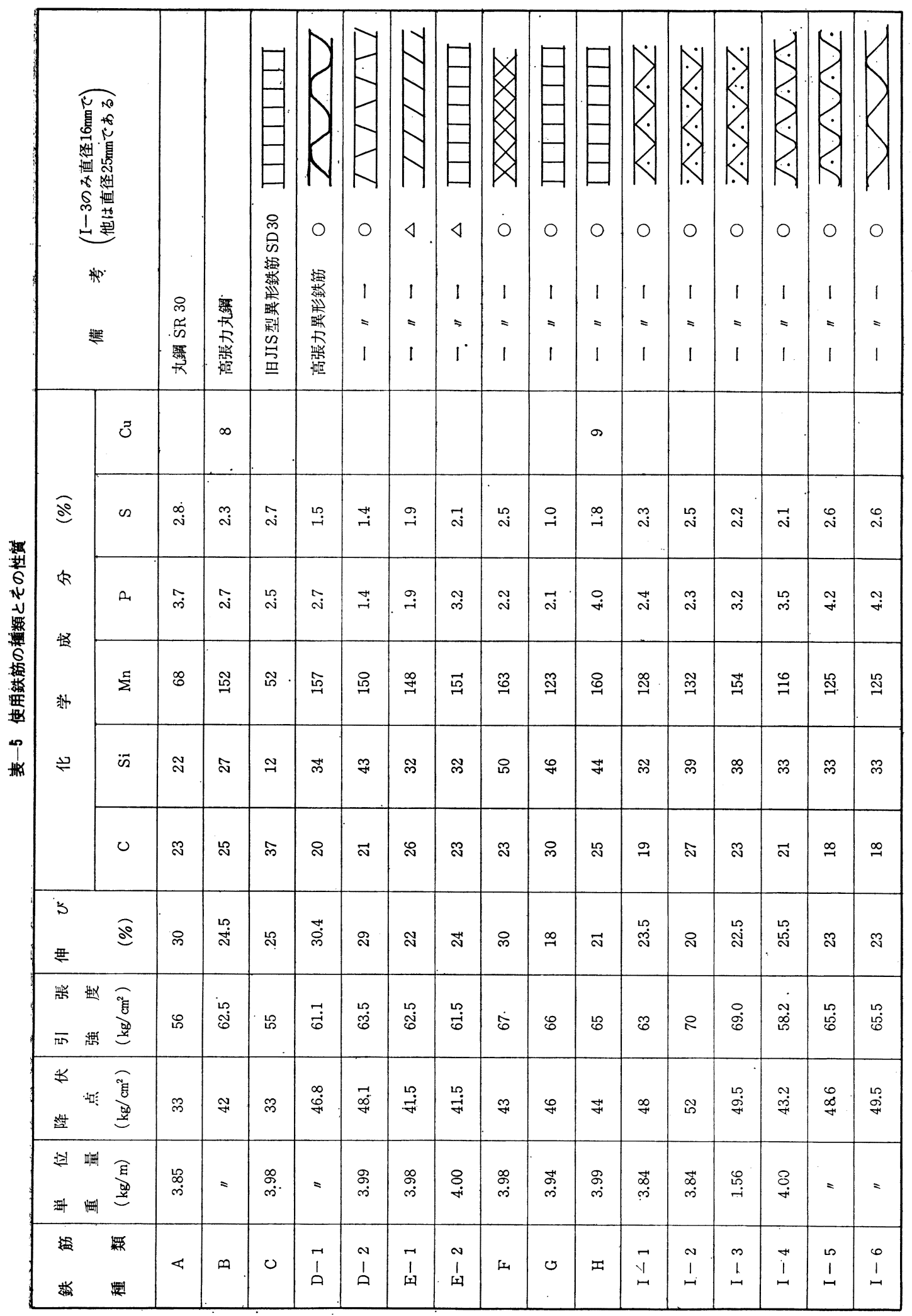


写兵一1 試験を行なった鉄筋の程類
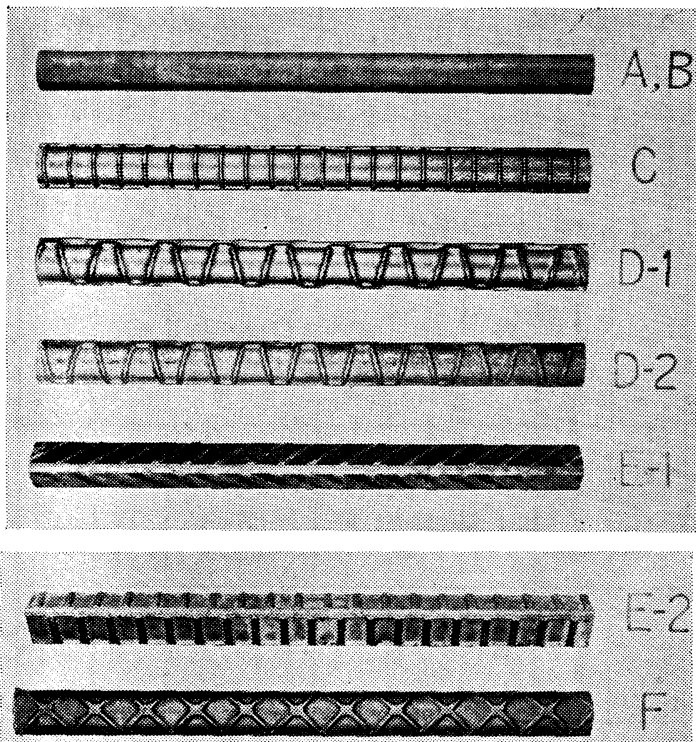

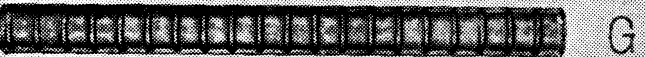

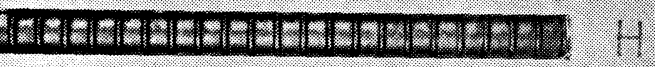

\section{- vaYayavavaYNavavar:}

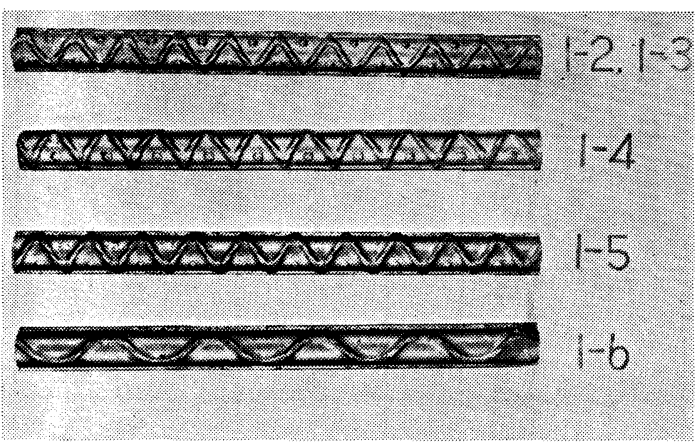

て 2 19.2 $\mathrm{t}$ の荷重のくり返しを行なった。試験ばりの 大部分がこの荷重段階で，つぎの $10^{6}$ 回以下の荷重のく り返しによって破壊したが，この $10^{6}$ 回（合計で $2 \times 10^{6}$ 回）の荷重くり返しに耐えたものについては, 荷重の上 限をさらに高めて 2 23t の荷重のくり返しを行なっ た。この場合の荷重 $16 \mathrm{t}$ における引張鉄筋およびコン クリートの常用設計方法による計算応力度 (コンクリー トの引張縁を無視し, 鉄筋とコンクリートとのヤング係 数の比を 15 として求めた值) は $2300 \mathrm{~kg} / \mathrm{cm}^{2}$ および $110 \mathrm{~kg} / \mathrm{cm}^{2}$ であるから, 鉄筋およびコンクリートの第 1 段階の振幅応力度の計算值は $300 \sim 2300 \mathrm{~kg} / \mathrm{cm}^{2}$ および $10 \sim 110 \mathrm{~kg} / \mathrm{cm}^{2}$ である。この荷重の大きさは試験装置
写真一2 試 釱 装

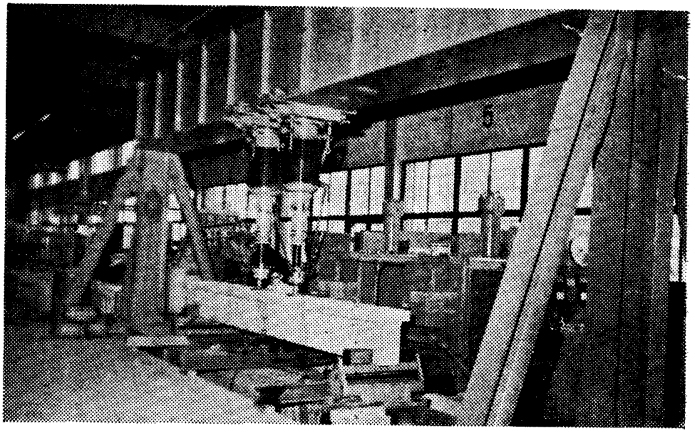

と試験ばりとの間にそう入したロードセル（直径 60 $\mathrm{mm}$, 高さ $100 \mathrm{~mm}$ の丸鋼にワイヤ ストレィンゲージ を 8 枚縦横に貼ってブリッジに組んだもの) によって検 定を行なった。引張鉄笳に 6-D ф16 mm を用いた試験 ばりの疲労荷重試験は上記の集中 2 点荷重の合計を 2 $12.5 \mathrm{t}$ に変化させてまず $10^{6}$ 回くり返し載荷し, その後 荷重の上限のみ高め 2 15 t の荷重のくり返しを行なっ た。この場合の荷重 $2 \sim 12.5 \mathrm{t}$ に対する鉄筋およびュン クリートの計算応力度の振幅は $400 \sim 2400 \mathrm{~kg} / \mathrm{cm}^{2}$ およ び $10 \sim 90 \mathrm{~kg} / \mathrm{cm}^{2}$ である。

疲労荷重試験においても静荷重試験と同様に, ワイヤ ストレィン ゲージによるコンクリート表面拉よ゙引張 鉄筋のひずみ測定，スパン中央および支承部のたわみ測 定,コンタクトゲージによるひびわれ幅測定およびひび われ観測とを行なった。この測定はまず疲労荷重試験前 に静的に集中 2 点荷重の合計を $2 \mathrm{t}$ おきに荷重の上限值 (16 t および $12.5 \mathrm{t}$ ) まで載荷して行ない, その後疲労 荷重試験中にも随時試験機の運転を止め上記と同様な試 験を行なった。特に $10^{6}$ 回の疲労荷重試験後において荷 重の上限值を高める際には, 入念な載荷試験とひびわれ 観測を行なった。また疲労試験機運転中にも，ブラウン 管式ひずみ計によってロード セル，鉄筋およびコンク リートのひずみ，たわみ，ひびわれなどの動的変化を測 定した。運転中の動的なたわみの測定には，燐青銅片に ワイヤストレィン ゲージを貼ったものを片持ばりの状 態ではりの下縁に接触させ，その測定したひずみの変化 よりたわみを求めることができる装置を用いた。同様に ひびわれの動的測定には，比較的大きなひびわれをまた いでワイヤ ストレィン ゲージを貼った燐青銅片をとり つけ，このひずみの変化よりひびわれ幅の変化を求める 装置を用いた。

\section{3．静荷重試験結果および考察}

本研究における静荷重試験は疲労荷重試験において不 用となった予備の試験ばりを用いて, 疲労荷重試験後に まとめて行なったので，その試験結果は完全のものでな いが，この結果について述べ，簡単な考察を加えること 
写真一3 破壞 状 態（静荷 重 試 験）
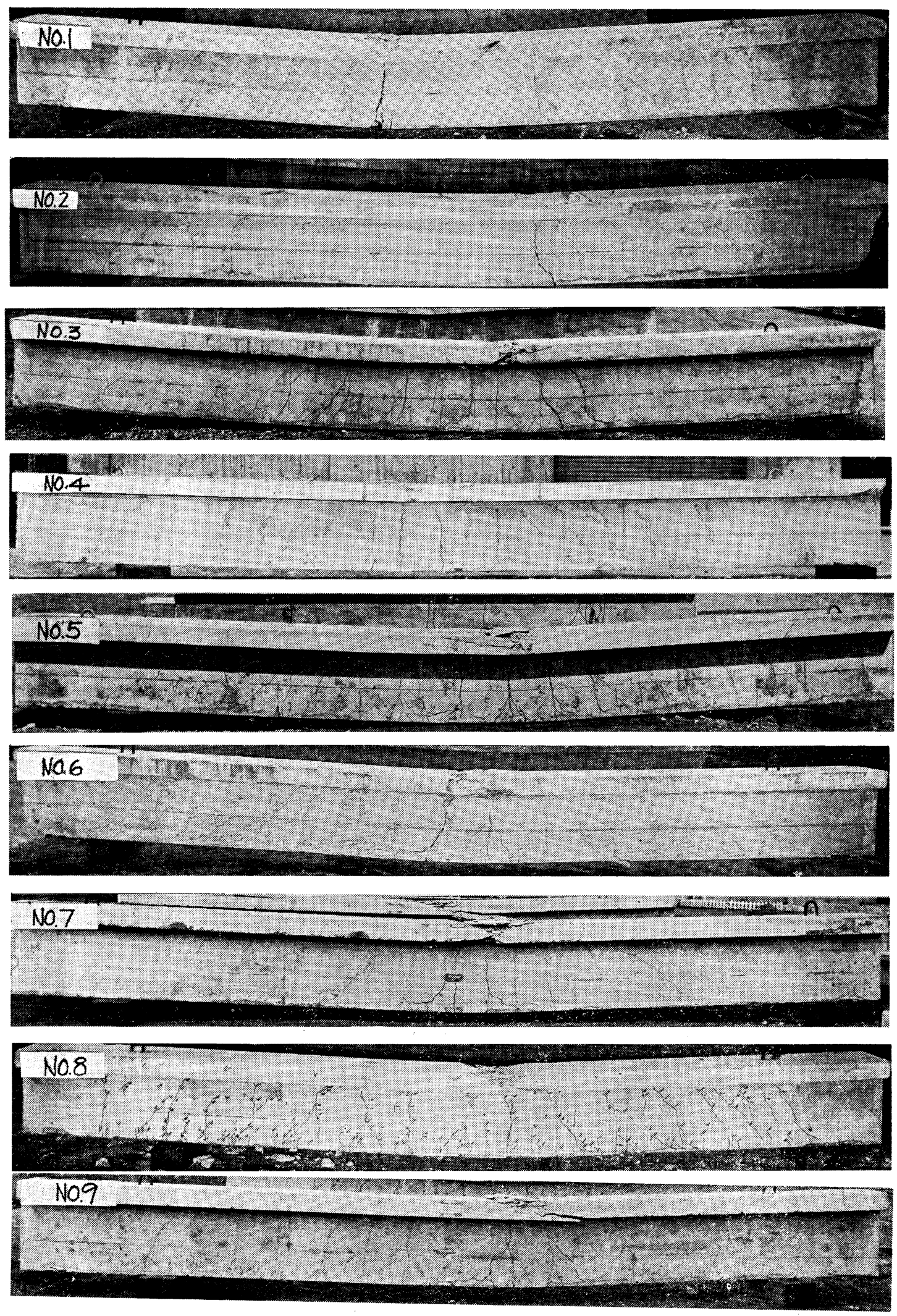
にする。静荷重試験を行なった 試験ばりはすべて引張鉄筋に 3-D $\phi 25$ を用いたもので，せ 儿断補強鉄筋は图一1に示すI 型およびII 型である。

\section{（1）破壊荷重}

静荷重試験を行なった 9 本の 試験ばりの破壊状態および試験 結果を一括して示すと 図一2,

写真一3，および 表一6 のとお りである。図一2 の中の数字は ひびわれ発生時の荷重を示す。 破壊状態はすべて引張鉄筋の降 伏による曲げ引張破壊で，まず 引張鉄筋が降伏点に達し，鉄筋 の塑性のびとともにはりの変形 が急激に增して圧縮縁のコンク リートが圧潰した（写真一 4,5 参照)。ただし高張力丸鋼 $\mathrm{B}$ を 用いた No. 2 の試験ばりは, 引張鉄筋が降伏した直後はり端 の鉄筋の定着部においてフック 部分のコンクリートに大きなひ びわれが入り, 定着部が破壊し た (写真-6 参照)。

これらの試験ばりのI 型のせ 儿断補強鉄筋は, 引張鉄筋の忘 力度が $2000 \mathrm{~kg} / \mathrm{cm}^{2}$ のときの 荷重を設計荷重 (14t) とし，こ れによるコンクリートのせん断 応力度 $8.6 \mathrm{~kg} / \mathrm{cm}^{2}$ を土木学会 鉄筋コンクリート標準示方書に 淮じてすべてせん断補強鉄筋で 抵抗するとして,このときのス ターラップの応力度を $1700 \mathrm{~kg} /$

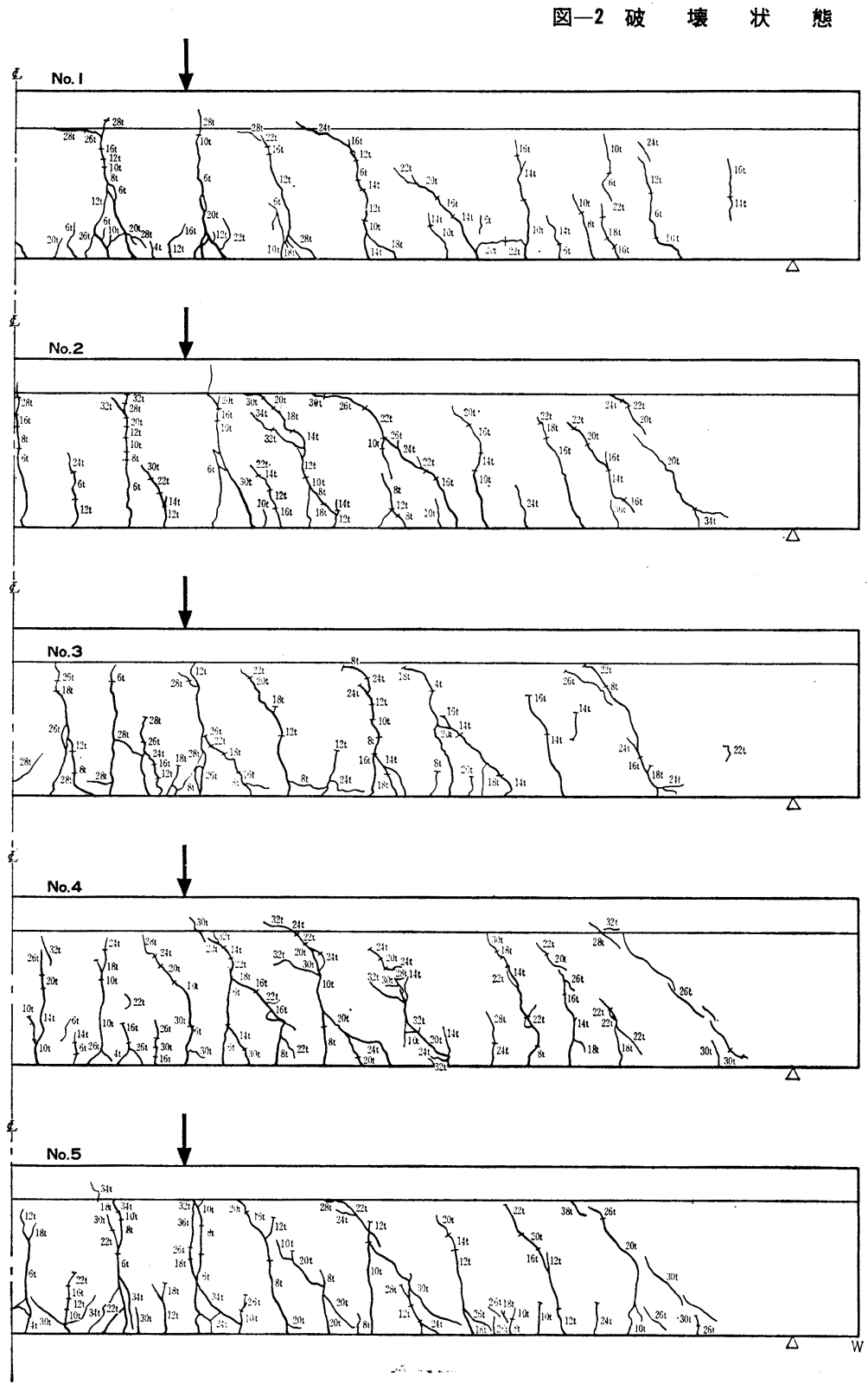

表一6 静 載 荷試 験 結 果

\begin{tabular}{|c|c|c|c|c|c|c|c|c|c|c|c|c|c|c|}
\hline \multirow{2}{*}{$\begin{array}{l}\text { 試験 } \\
\text { ばり } \\
\text { No. }\end{array}$} & \multirow{2}{*}{$\begin{array}{c}\text { 鉄筋 } \\
\text { の } \\
\text { 種類 }\end{array}$} & \multirow{2}{*}{$\begin{array}{l}\text { 材令28日にお } \\
\text { けるコンク咆 } \\
\text { 一トの強度 } \\
\sigma_{c}\left(\mathrm{~kg} / \mathrm{cm}^{2}\right)\end{array}$} & \multirow{2}{*}{$\begin{array}{l}\text { せん断 } \\
\text { 補強の } \\
\text { 種 類 }\end{array}$} & \multirow{2}{*}{$\begin{array}{c}\text { 鉄 筋 } \\
\text { 降 } \\
\text { 伏 点 } \\
\sigma_{s y} \\
\left(\mathrm{~kg} / \mathrm{mm}^{2}\right)\end{array}$} & 降 & 伏 & 破 & 壊 & \multicolumn{2}{|r|}{ 計 } & 算 & v & \multicolumn{2}{|c|}{ 較 } \\
\hline & & & & & $\begin{array}{l}\text { 荷重 } \\
(t)\end{array}$ & $\left|\begin{array}{l}\epsilon-x \\
2 ト \\
(t-m)\end{array}\right|$ & $\begin{array}{l}\text { 荷重 } \\
(\mathrm{t})\end{array}$ & $\left|\begin{array}{c}\epsilon-\lambda \\
2+ \\
(t-m)\end{array}\right|$ & $\underset{(\mathrm{t}-\mathrm{m})^{2}}{M_{\mathrm{cat}}}$ & $M_{u} / M_{\mathrm{ca}:}$ & $M_{u^{\prime}} / M_{\mathrm{cal}}$ & $\underset{(\mathrm{t}-\mathrm{m})}{M_{\mathrm{ca} \mathrm{l}^{\prime}}{ }^{* * *}}$ & $M_{u} / M_{\mathrm{ca} !^{\prime}}$ & $M_{u^{\prime}} / M_{\mathrm{cal}^{\prime}}$ \\
\hline 1 & A & 380 & $I$ & 33 & 26 & 23.4 & 31 & 27.9 & 21.6 & 1.08 & 1.29 & $20.3(20.5)^{* * *}$ & 1.15 & 1.38 \\
\hline 2 & B & 310 & I & 42 & 30 & 27 & 37.4 & 33.6 & 26.8 & 1.01 & 1.26 & $25.9(26.2)$ & 1.04 & 1.30 \\
\hline 3 & $\mathrm{C}$ & 380 & I & 33 & 24 & 21.6 & 32 & 28.8 & 21.6 & 1.00 & 1.33 & $20.3(20.5)$ & 1.06 & 1.41 \\
\hline 4 & D-1 & 320 & I & 46.8 & 30 & 27 & 35 & 31.5 & 29.7 & 0.91 & 1.06 & $28.8(29.1)$ & 0.94 & 1.09 \\
\hline 5 & E-1 & 320 & $I$ & 41.5 & 30 & 27 & 40 & 36 & 26.5 & 1.02 & 1.36 & $25.6(25.9)$ & 1.05 & 1.36 \\
\hline 6 & $\mathrm{~F}$ & 390 & II & 43 & 36 & 32.4 & 40.2 & 36.2 & 27.8 & 1.16 & 1.30 & $26.5(26.8)$ & 1.27 & 1.37 \\
\hline 7 & $\mathrm{H}$ & 390 & II & 44 & 38 & 34.2 & 42.4 & 38.2 & 28.4 & 1.21 & 1.34 & $27.1(27.4)$ & 1.26 & 1.40 \\
\hline 8 & I -4 & 330 & II & 43.2 & 30 & 27 & 39 & 35.1 & 27.8 & 0.97 & 1.26 & $26.6(26.9)$ & 1.02 & 1.37 \\
\hline 9 & I -5 & 390 & II & 48.6 & 36 & 32.4 & 43 & 38.7 & 31.2 & 1.04 & 1.24 & $29.9(30.3)$ & 1.08 & 1.30 \\
\hline
\end{tabular}

* $M_{\mathrm{cal}}=A_{s} \sigma_{s y} d\left(1-\frac{p}{2} \frac{\sigma_{s y}}{0.85 \sigma_{c}}\right) \quad * * \quad M_{\mathrm{cal}}{ }^{\prime}=A_{s} \sigma_{s y} j d \quad j=\frac{6-6(t / d)+2(t / d)^{2}+(t / d)^{3 / 2} n p}{6-3(t / d)}$

*** $n=15$ としての計算值で（）内は $n=7$ としての值を示す。 


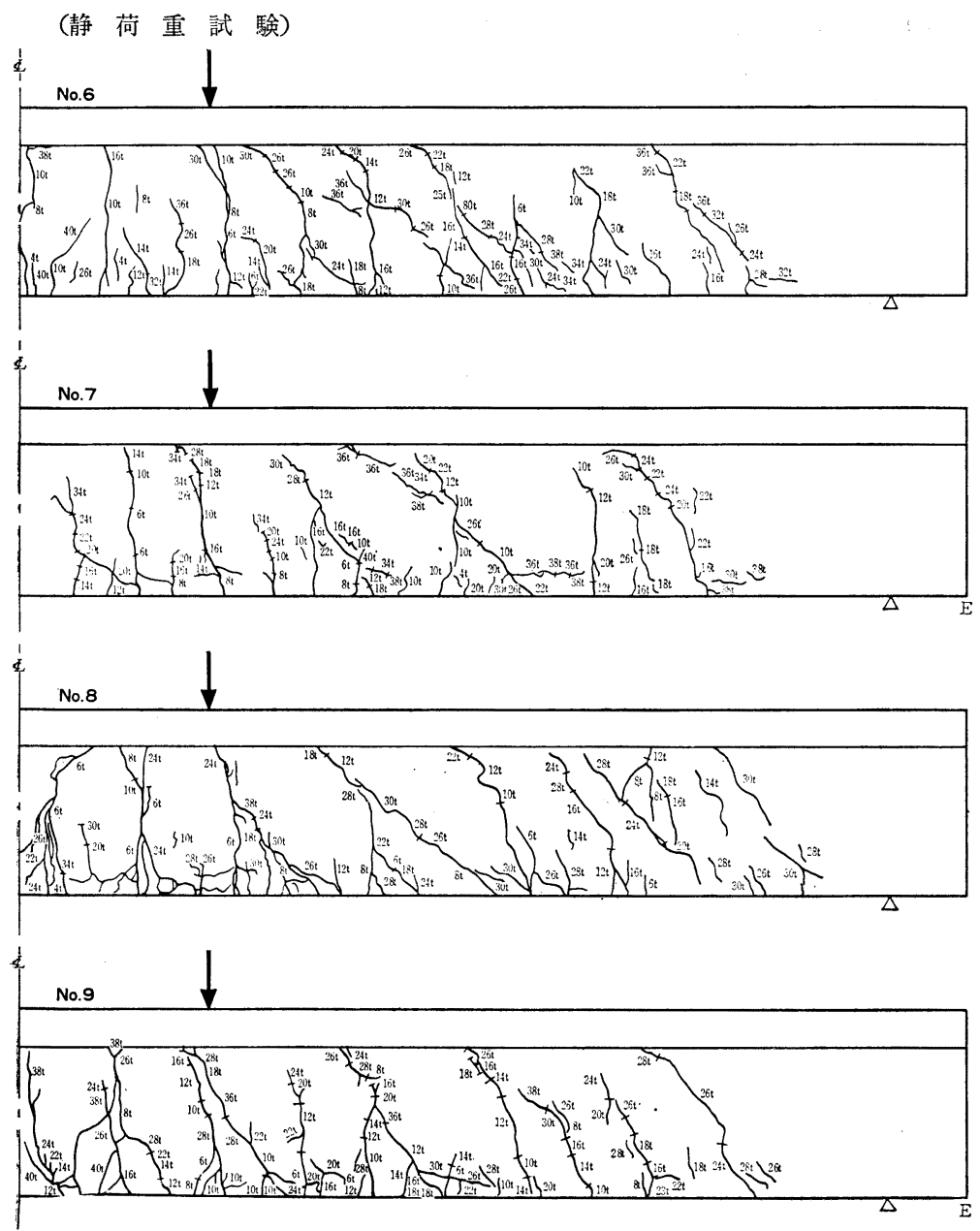

た。この結果より, 静荷重に対 してはせん断破壊は曲げ破壊よ りおこりにくいといえる。

この曲げ引張破壊強度につい て極限強度計算式によって検討 して見る。極限強度の計算式と しては多くの提案があるが，こ こでは ACI Building Codeの Ultimate Strength Design の計算式のもとになっいる Whitney の極限強度式㧍よび 常用設計方法の鉄筋応力度の算 定式に鉄筋の降伏点を代入して 破壊モーメントを求める方法と を用いて比較する。この試験 ばりのようにコンクリートの圧 縮幅が圧縮フランジの中に入る 場合には，Whitney の式はつ ぎのような矩形ばりの式にな る。

$$
\begin{aligned}
M_{\mathrm{cal}} & =A_{s} \sigma_{s y} d \\
& \left(1-\frac{p}{2} \frac{\sigma_{s y}}{0.85 \sigma_{c}}\right)
\end{aligned}
$$

ここに $A_{s}$ : 引張鉄筋の断面積 $d:$ はりの有効高さ $b:$ 圧縮フランジの幅 $p: A_{s} / b d$ で定義され る引張鉄筋比

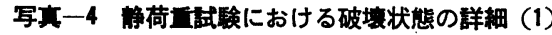

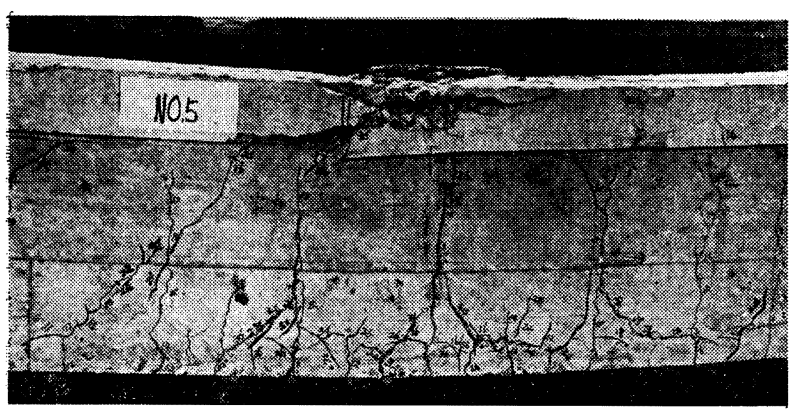

$\sigma_{s y}:$ 鉄筋の降伏点

$\sigma_{c}:$ コンクリートの強度

また常用設計方法による破壊モーメントの計算 式はつぎのようになる。

$$
j=\frac{6-6\left(\frac{t}{d}\right)+2\left(\frac{t}{d}\right)^{2}+\left(\frac{t}{d}\right)^{3} / 2 n p}{6-3\left(\frac{t}{d}\right)}
$$

ここに $n:$ 鉄筋とコンクリートとのヤング係数比 $(n=15)$

$t:$ 圧縮フランジの厭さ

表一6 は試験ばりの降伏荷重および破壊荷重より求め た降伏モーメントおよび破壊モーメントと上記式 (1) お よび式（2）による計算値とを比較して示したものであ る。この降伏荷重とは試験ばりのひずみおよびたわみが 急激に増加し始めた荷重, 破壊荷重とははりの破壊時の 最大荷重である。これより降伏モーメントは計算值の $0.9 \sim 1.3$, 破壊モーメントは計算值の $1.1 \sim 1.4$ 倍で計 算値はいずれも一般に安全側の結果を与えている。
びそのスターラップを規定量の約 $1 / 2$ 以下にしたものに ついてもせん断破壊が曲げ破壊に先行することはなかっ

$\mathrm{cm}^{2}$ にとって設計したものである。II型はＩ型のスター に対するスターラップの計算応力度は $3800 \mathrm{~kg} / \mathrm{cm}^{2}$ で ある。折曲鉄筋のある部分のスターラップおよび折曲鉄 筋の応力度はいずれの場合も約 $300 \mathrm{~kg} / \mathrm{cm}^{2}$ 程度で, そ の值はきわめて小さいが，この試験においては土木学会 の規定より若干少ないスターラップを配置したものおよ 
写索一5 静荷重試験における破壊状態の詳細（2）

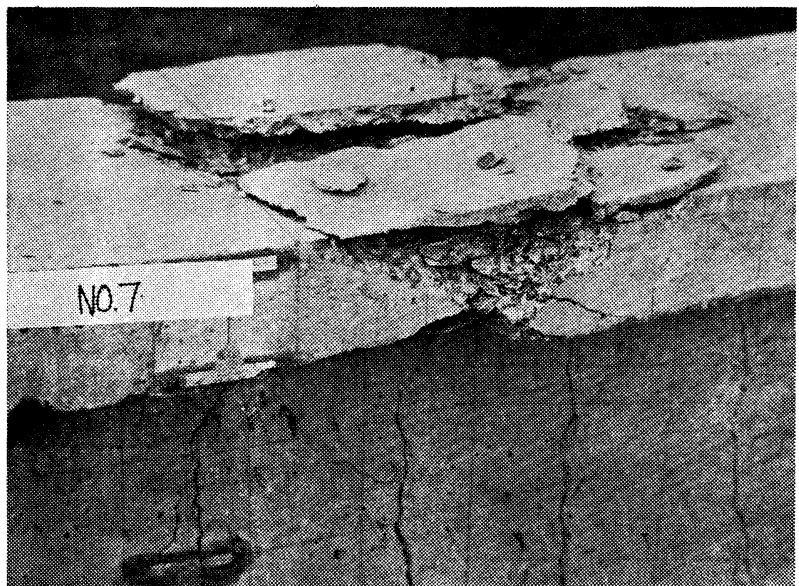

図一3 コンクリートのひずみ（静荷重試験）

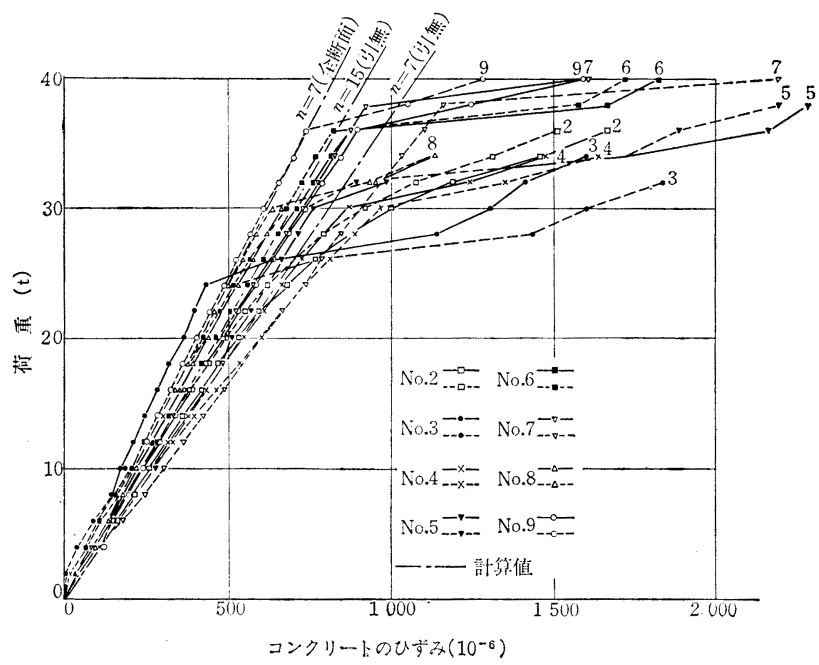

図一4 鉄筋のひずみ（静荷重試験）

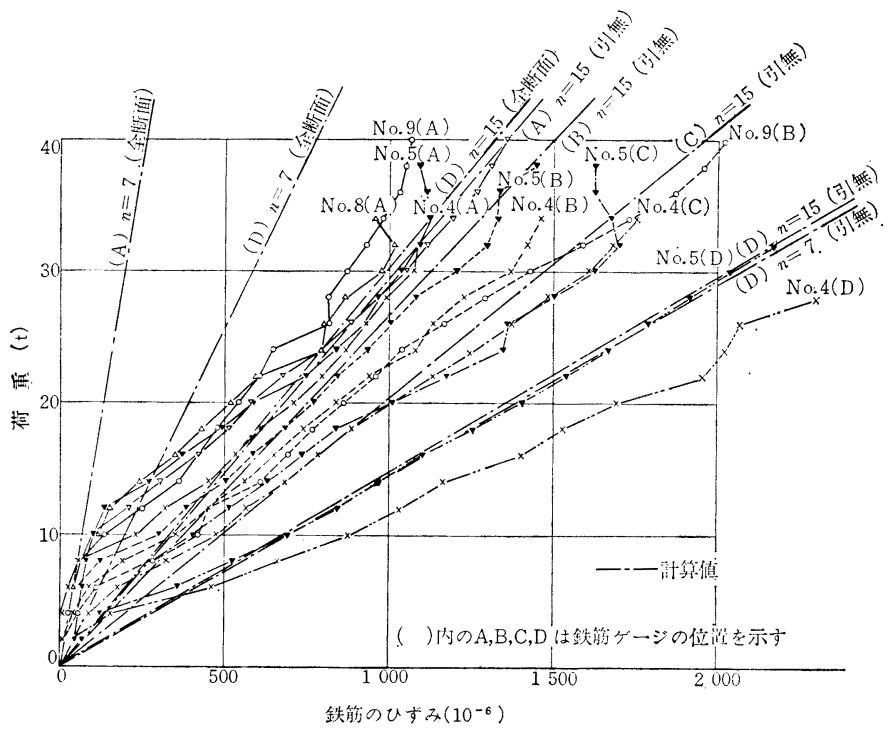

写索一6 静荷直式験における定着部破壤の状慜

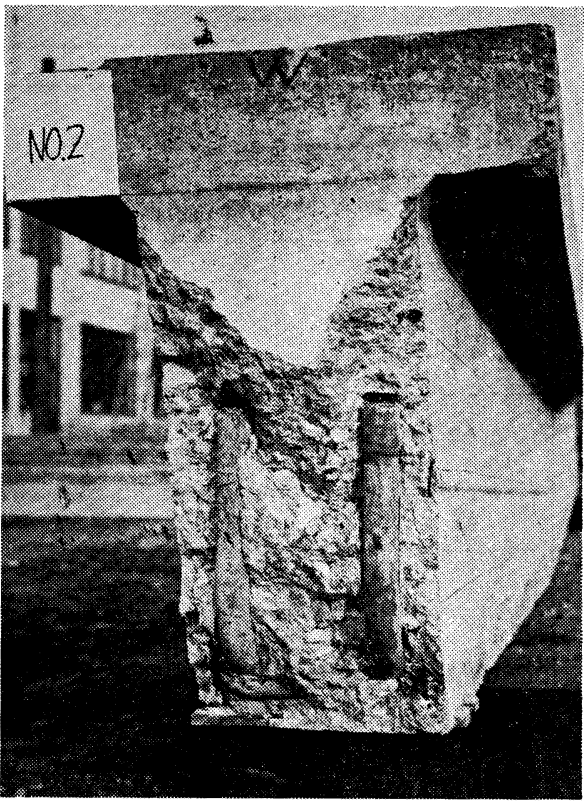

（2）コンクリートのひずみ

スパン中央のコンクリートの表面にワイヤス トレィンゲージをはってひずみ測定を行なっ たが，圧縮フランジの側面上部に貼った 2 箇所 のワイヤ ストレィン ゲージ(上面より $10 \mathrm{~mm}$ の位置)によるひずみ測定結果を示すと 図一3 のようになる。図中の No. は試騃ばりの番号 で，鎖線は計算值である。ここには鉄筋とコン クリートとのヤング係数比 $n$ を 7 および 15 と しコンクリートの中立軸以下の引張縁を無視し て求めたコンクリートの忘力度より, そのヤン

グ係数を $3 \times 10^{5} \mathrm{~kg} / \mathrm{cm}^{2}$ として計算したひ ずみの計算值および全断面有効としてコン クリートのヤング係数を $3 \times 10^{5} \mathrm{~kg} / \mathrm{cm}^{2}$ と して求めたひずみの計算值 $(n=7)$ を示し てある。この結果よりすれば，鉄筋比 $n$ を 7 とし引張縁を無視して求めた計算值が比 較的安全側の結果を与えている。なおこの 試験ばりのコンクリートのヤング係数は約 $3 \times 10^{5} \mathrm{~kg} / \mathrm{cm}^{2}$ である。

\section{(3) 鉄筋のひずみ}

鉄筋のひずみ測定ができたものは比較的 少ないが，これを一括して示すと図一4の ようになる。このうち $\mathrm{A}, \mathrm{B}, \mathrm{C}, \mathrm{D}$ とある のは図一1に示す鉄筋のひずみの測定点, No. は試験ばりの番号で, 鎖線はその計算 值である。ここには D点についてはコンク リートの全断面有効とした場合および引張 
縁を無視した場合とについて，鉄筋のヤング係数を 2.1 $\times 10^{6} \mathrm{~kg} / \mathrm{cm}^{2}$ ，コンクリートのヤング係数を $3 \times 10^{5} \mathrm{~kg} /$ $\mathrm{cm}^{2}$ および $1.4 \times 10^{5} \mathrm{~kg} / \mathrm{cm}^{2}(n=7$ および 15) として 求めた計算值を， A点についてはコンクリートのヤング 係数を $3 \times 10^{5} \mathrm{~kg} / \mathrm{cm}^{2}(n=7)$ とし，全断面有効として 求めた計算值およびコンクリートのヤング係数を $1.4 \times$ $10^{5} \mathrm{~kg} / \mathrm{cm}^{2}(n=15)$ とし引張縁を無視して求めた計算值 を， $\mathrm{B}$ 点および $\mathrm{C}$ 点についてはコンクリートのヤング係 数を $1.4 \times 10^{5} \mathrm{~kg} / \mathrm{cm}^{2}(n=15)$ とし, コンクリートの引 張縁を無視して求めた計算值を示してある。

鉄筋のひずみの測定結果はかなりばらついているが， 荷重の小さい範囲では実測值は全断面有効として求めた 計算値に近い值を示している。荷重が増大してひびわれ が発達してくると, 引張縁を無視して求めた計算值と実 測值の最大のものとが，ほぼ一致してくる。この場合の 計算值としてはコンクリートのヤング係数を $3 \times 10^{5} \mathrm{~kg} /$ $\mathrm{cm}(n=7)$ として求めた值と $1.4 \times 10^{5} \mathrm{~kg} / \mathrm{cm}^{2}(n=15)$ として求めた值との差はきわめて小さい。鉄筋のひずみ の実測值はかなりばらついているが，これは次章で示す 疲労荷重試験結果についてもいえることで, 鉄筋のひず みの測定位置とひびわれとの相対位置関係によるものと 思われる。鉄筋のひずみおよび応力は最大のところでは ほぼ $n=15$ とし引張縁を無視して求めた計算值に近い ものになっている。

\section{(4) ひびわれ}

試験ばりに加える荷重が増加して鉄筋の引張応力度が $300 \mathrm{~kg} / \mathrm{cm}^{2}$ 程度に達すると，スパン中央部分のコンタ クトゲージの測定值が数箇所で急激に大きくなり，ほ ぼ同時に 10 数本の曲げひびわれが $10 \sim 20 \mathrm{~cm}$ 間隔に 発生した。丸鋼を用いたはりでは，さらに荷重を増して もその間に生ずる曲げひびわれは比較的少ないが，異形 鉄筋を用いたはりでは，鉄筋応力度が $2000 \mathrm{~kg} / \mathrm{cm}^{2}$ 程 度になるまでの間にその間に数本の新しい曲げひび われが発生した。このひびわれ幅は一般に荷重とと もにほぼ直線的に増大した。曲げひびわれの発生 後, せん断スパンに斜め引張ひびわれが発生し, 荷 重増加にともなってこのひびわれも数と幅とが増大 した。また引張鉄筋に添って水平なひびわれも発生 した。これらのひびわれの様子は 図一2, 写真一3 に示すようである。

試験ばり腹部の引張鉄筋位置におけるコンタクト ゲージによるひびわれ幅の測定值のうち, 最大のも の 2 個の平均值を最大曲げひびわれ幅として, 荷重 との関倸を示すと図一5のようになる。これより丸 鋼を用いた試験ばりの最大曲げひびわれ幅は異形鉄 筋を用いたはりのものよりも約 1.1〜1.3\%大き
図一5 最大曲げひびわれ幅（静荷重試験）

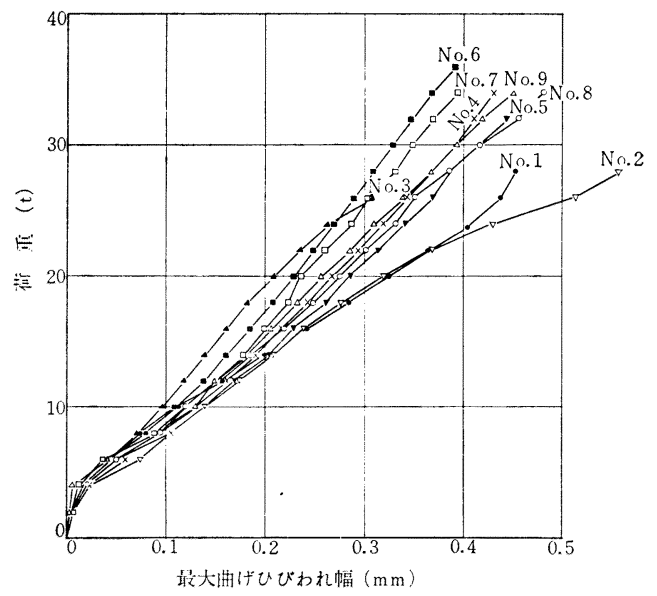

表一7 最大ひびわれ幅（静荷重試験）

\begin{tabular}{|c|c|c|c|c|c|c|}
\hline \multirow[b]{2}{*}{ 重 $(t)$} & \multicolumn{3}{|c|}{$\begin{array}{c}\text { 最大ひひびわれ幅 } \\
(\mathrm{mm})\end{array}$} & \multicolumn{3}{|c|}{$\begin{array}{c}\text { 最大ひびわれ幅の平均值 } \\
(\mathrm{mm})\end{array}$} \\
\hline & 7 & 14 & 21 & 7 & 14 & 21 \\
\hline 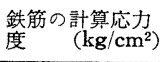 & 1000 & 2000 & 3000 & 1000 & 2000 & 3000 \\
\hline 銅 (A) & $|\stackrel{0.058}{\sim 0.050}|$ & $\begin{array}{l}0.200 \\
\sim 0.208\end{array}$ & $\left|\begin{array}{l}0.343 \\
\sim 0.346\end{array}\right|$ & 0.074 & 0.204 & 0.345 \\
\hline 異形鉄筋 (B) & $\underset{\sim}{0.059} \sim 0.079$ & \begin{tabular}{l|}
0.140 \\
$\sim 0.206$
\end{tabular} & $\mid$\begin{tabular}{l|}
0.223 \\
$\sim 0.360$
\end{tabular} & 0.069 & 0.178 & 0.264 \\
\hline $\mathrm{A} / \mathrm{B}$ & - & - & - & 1.072 & 1.146 & 1.308 \\
\hline
\end{tabular}

い。表-7 はこの最大曲げひびわれ幅を荷重 $7 \mathrm{t}, 14 \mathrm{t}$, $21 \mathrm{t}$ について比較して示したもので, この荷重における 引張鉄筋の計算応力度はそれぞれ $1000 \mathrm{~kg} / \mathrm{cm}^{2}, 2000$ $\mathrm{kg} / \mathrm{cm}^{2}, 3000 \mathrm{~kg} / \mathrm{cm}^{2}$ である。異形鉄笳のひびわれ幅に およぼす効果は鉄筋の応力度が大きくなるほど大きいこ とを示している。
(5) たわみ

たわみはスパン中央部と支承部について測定を行なっ 図一6たわみ(静荷重試験)

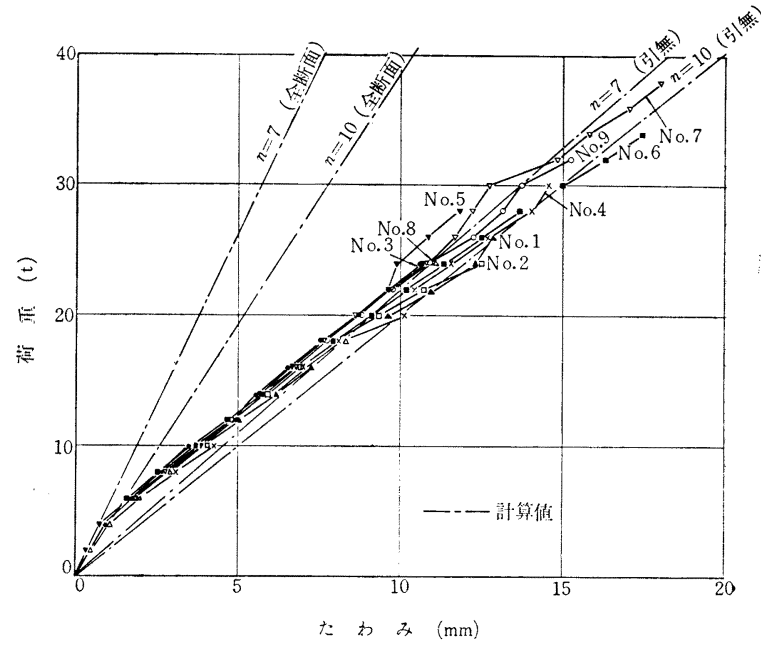


たが，スパン中央部の測定值よ り両端の支承部の測定值の平均 を減じて修正したスパン中央の 実たわみをまとめて示すと図 一6 のようになる。このうち鎖 線はコンクリート全断面有効と した場合と引張縁を無視した場 合とについて，鉄筋のヤング係 数を $2.1 \times 10^{6} \mathrm{~kg} / \mathrm{cm}^{2}$, コンクリ 一トのヤング係数を $3.0 \times 10^{5}$ $\mathrm{kg} / \mathrm{cm}^{2}$ および $2.1 \times 10^{5} \mathrm{~kg} / \mathrm{cm}^{2}$ ( $n=7$ および 10$)$ とした計算值 を示したもので，実たわみは荷 重の小さい範囲では全断面有効 として求めた值に，荷重が大き くなってひびわれが発達してく ると引張縁を無視して求めた值 に一致してくる。実際のはりの たわみとしては活荷重によるも のが問題になるが，この試駼結 果よりすれば引張縁を無視して 求めた値が実用的と思われる。

\section{4. 疲労荷重試験結果お よび考察 (I)}

疲労荷重試験を行なった試験 ばりは全部で 20 本であるが， このらち現在の市販されている 代表的な鉄筋を用いた試験ばり 7 本と丸鋼を用いた試験ばり 2 本とについて試験結果を整理 し，考察を加えることにする。 写真一7 は疲労荷重試験の状態 を示したものである。

\section{（1）破壊荷重}

疲労荷重試験を行なった代表的な試験ばりの破 壊状態および試験結果を一括して示すと 図一7, 写真一8 および 表一7 のと抒りである。図一7 の 中の普通の数字は最初の荷重載荷によるひびわれ 発生時の荷重を示し，わく内の数字は疲労荷重に よって成長したひびわれについて，荷重のくり返 し回数を $10^{4}$ 単位で示したものである。破壞状態 は丸鋼Bを用いた試験ばり No. 2 を除いてすべ て引張鉄笳の疲労破断によるもので，あるくり返 し回数において急激に引張鉄筋が破断し，破壊音 を発して試験ばりが破壊した。試験ばりの静荷重 試験による破壊においては，はりの変形, ひびわ れなどがある一定の荷重（降伏荷重）を境にして
図-7 破 壤 状 態（疲労荷重試験）
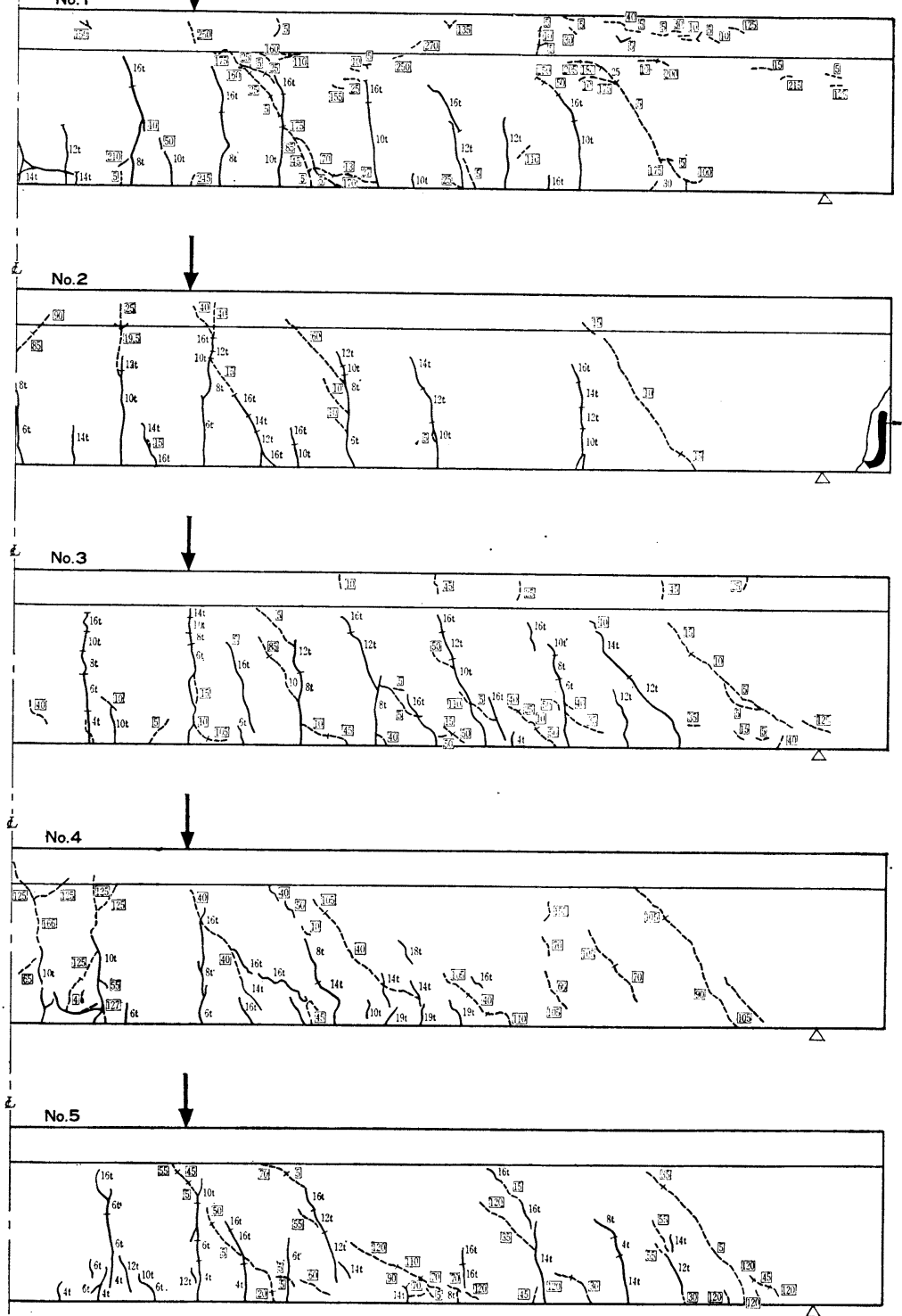

写真一7 疲労荷重試験の状態

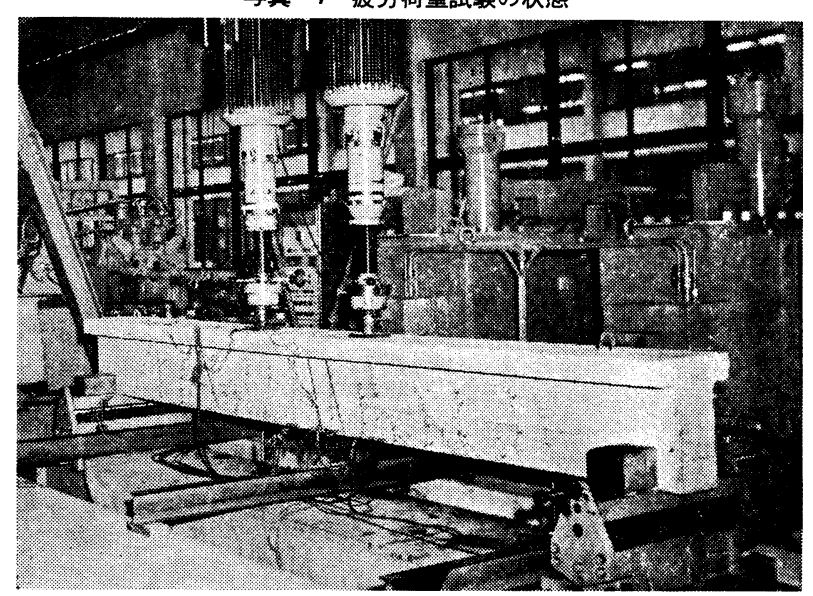




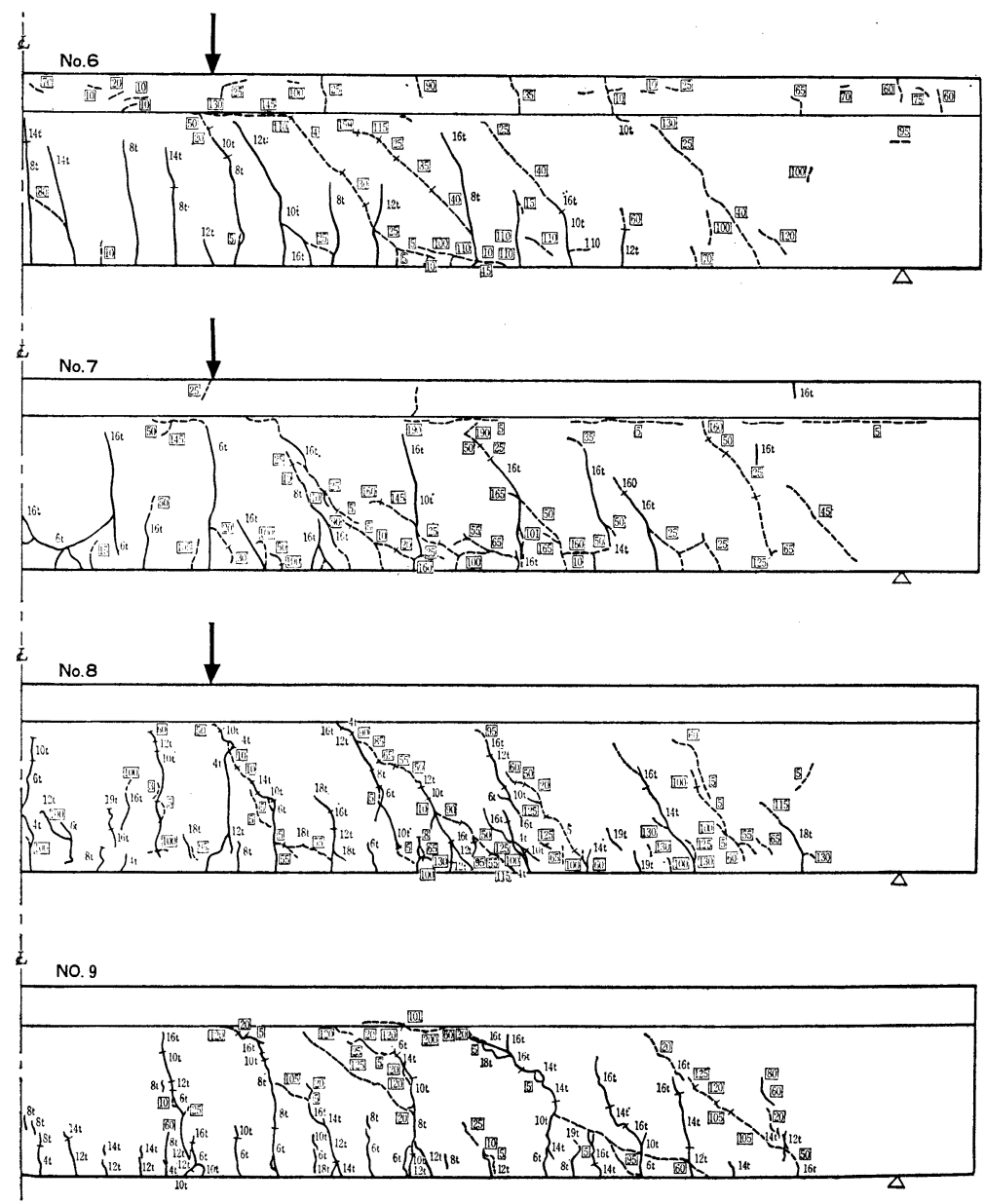

はりについてはその疲労強度を 十分に考慮して設計するととも に, 疲労性状のよい鉄筋を用い ることが大切であることを示し ている。

ここに示した試験ばりはすべ て 2 16 $\mathrm{t}$ の荷重に対して $10^{6}$ 回のくり返しに耐え, その後荷 重の上限のみ高めた 2 19.2 $\mathrm{t}$ の荷重に対して大部分が $3 \times$ $10^{5} \sim 6 \times 10^{5}$ 回のくり返して破 壊している。この破壊状態につ。 いて丸鋼を用いた場合，異形鉄 筋を用いI 型のせん断補強をし た場合，異形鉄筋を用いII型の せん断補強をした場合とに分け て考察を加える。ここにI 型の せん断補強とは, 静荷重試験に おいて示したように引張鉄筋の 計算応力度が $2000 \mathrm{~kg} / \mathrm{cm}^{2}$ の ときの荷重 (14t) による全せ ん断力をスターラップのみで抵 抗するものとして, このスター ラップの応力度を $1700 \mathrm{~kg} / \mathrm{cm}^{2}$ にとって設計したもので（折曲 鉄筋の部分のスターラップの応 力度は約 $300 \mathrm{~kg} / \mathrm{cm}^{2}$ ), II型の

表一8 疲労荷重試験による破壊荷重 (I)

\begin{tabular}{|c|c|c|c|c|c|c|c|}
\hline \multirow{2}{*}{$\begin{array}{l}\text { 試験 } \\
\text { ばり } \\
\text { No. }\end{array}$} & \multirow{2}{*}{$\begin{array}{c}\text { 鉄筋 } \\
\text { の } \\
\text { 種類 }\end{array}$} & \multirow{2}{*}{$\begin{array}{c}\text { 材令28日にお } \\
\text { けっコンクリ } \\
\text { ートの強度 } \\
\left(\mathrm{kg} / \mathrm{cm}^{2}\right) \\
\end{array}$} & \multirow{2}{*}{$\left|\begin{array}{ll}\text { せん断 } \\
\text { 補 } & \text { 強 }\end{array}\right|$} & \multicolumn{3}{|c|}{ くり返 ᄂ 回数 $\left(10^{4}\right)$} & \multirow[b]{2}{*}{ 破 壊 状 態 } \\
\hline & & & & $\begin{array}{c}2 \sim 16 \mathrm{t} \\
(1)\end{array}$ & $\begin{array}{c}2 \sim 19.2 \mathrm{t} \\
(2)\end{array}$ & $\begin{array}{c}2 \sim 23 \mathrm{t} \\
(3)\end{array}$ & \\
\hline 1 & A & 380 & I & 154 & $284(130)^{*}$ & $298(14)^{* *}$ & 中央の鉄筋破断 \\
\hline 2 & B & 310 & I & 100 & $192(92)$ & - & 定着部破壊 \\
\hline 3 & $\mathrm{C}$ & 390 & I & 105 & $161(56)$ & - & 中央の鉄筋破断 \\
\hline 4 & D-1 & 280 & $I$ & 100 & 128 (28) & - & $\Rightarrow$ \\
\hline 5 & E-1 & 310 & I & 100 & 127 (27) & - & $"$ \\
\hline 6 & $\mathrm{~F}$ & 380 & II & 100 & $150(46)$ & - & $"$ \\
\hline 7 & G & 380 & II & 104 & $210(106)$ & $255(45)$ & " \\
\hline 8 & $\mathrm{H}$ & 380 & II & 109 & $134(25)$ & - & $\begin{array}{l}\text { せん断ひびわれより } \\
1 / 4 \text { 点で鉄筋破断 }\end{array}$ \\
\hline 9 & $I-4$ & 370 & III & 100 & $129(29)$ & - & $\leadsto$ \\
\hline
\end{tabular}

せん断補強はI 型のスターラップの量を 約 $1 / 2$ にしたものである。

丸鋼を用いた試験ばりのうち No. 1 は市販されている SR 30 の普通丸鋼を 用いたもので, No. 3 以下の高張力異 形鉄筋を用いた試験ばりと比較して，そ の疲労強度はいちじるしく高い。すなわ ち $2 \sim 16 \mathrm{t}$ の荷重の $1.5 \times 10^{6}$ 回のくり 返しの後, さらに2 19.2t の荷重の. $1.3 \times 10^{6}$ 回のくり返しに耐え, その後の $2 \sim 23 \mathrm{t}$ の荷重の $1.4 \times 10^{5}$ 回のくり返し で破壊した。異形鉄筋を用いた試験ばり の大部分は $2 \sim 19.2 \mathrm{t}$ の荷重段階で合計で $1.3 \times 10^{6} \sim$ $1.6 \times 10^{6}$ 回の荷重のくり返しで破壊したが, これと比較 すると丸鋼を用いたはりははるかに高い疲労強度を持っ ている。No. 2 の試験ばりは高マンガンの高張力鋼によ る丸鋼を用いたもので, この試験のために特に圧延した ものであるが，2 19.2 $\mathrm{t}$ の荷重段階でせん断ひびわれ より引張鉄筋に沿う水平ひびわれが試験ばりの端部まで 成長し, 鉄筋の定着部のコンクリートが破壊し, 引張鉄 筋がすべり出してはりが破壊した。これは他の試験ばり りかなり小さい。これらのことはくり返し荷重をうける 労破壊荷重は表一6に示寸静荷重試験による破壊荷重よ

急激に大きくなるので，はりの破壊をある程度予知する ことができたが，疲労破壊においては鉄筋の疲労破断の 前にはりの変形，ひびわれなどの急激な変化がなく，突 然にその破壊が生じた。また大部分の試験ばりは 表一8 で示すように $10^{6} \sim 2 \times 10^{6}$ 回の疲労荷重のくり返しによ って 16〜19.2t の上限荷重で破壊しているので，破壊 時におけるひびわれの発生は比較的少なく, またこの疲 
写真一8 破 壊 状 態（疲労荷重試験）
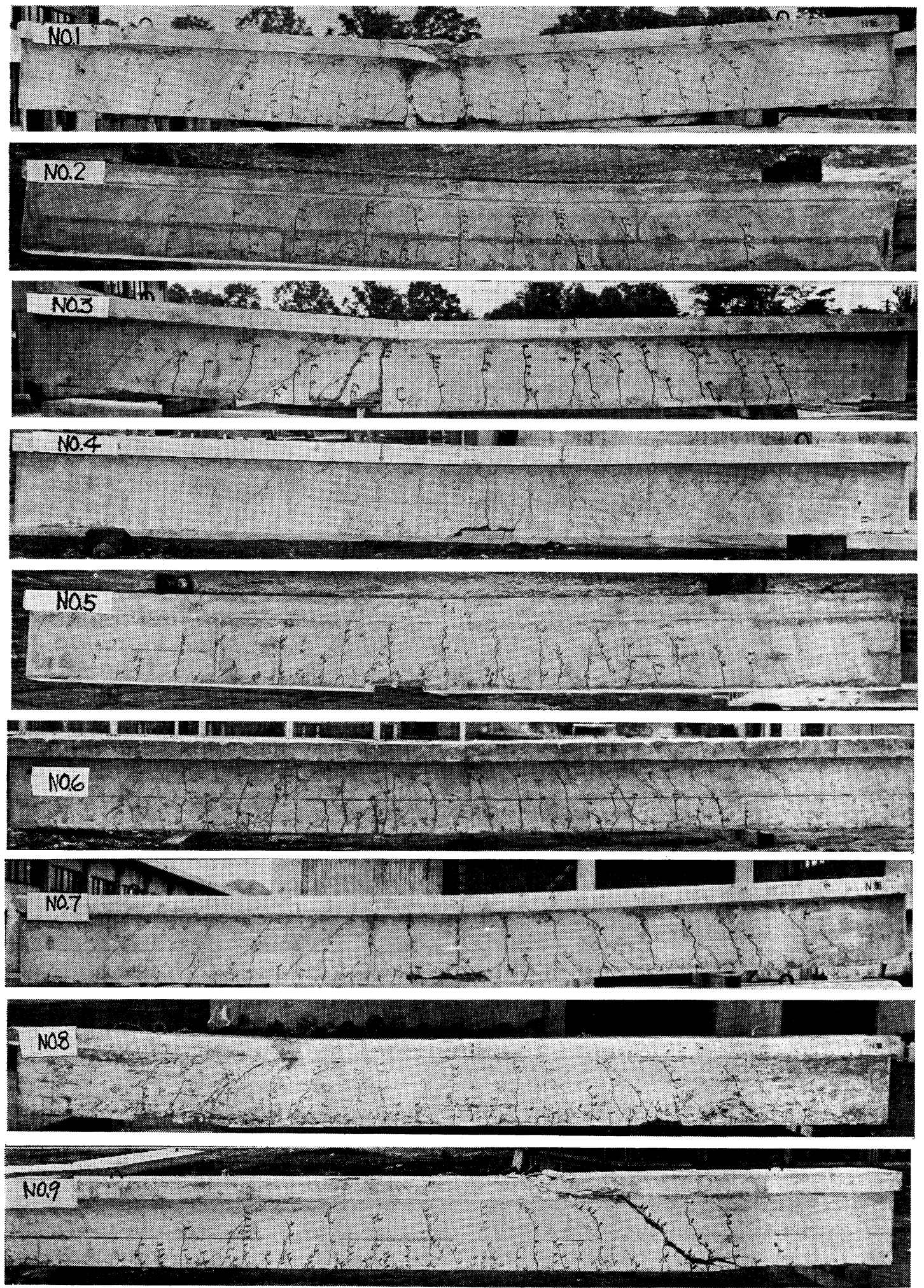

がすべて鉄筋の疲労破断によって破壊しているのと異な っているところで, 引張鉄筋は破断していない（写真一
9 参照)。またその破壊荷重も No. 1 の場合より小さ い。この理由は No. 1 に用いた丸鋼は普通市販品で, 
写真一9 丸鋼の疲労破壊状態

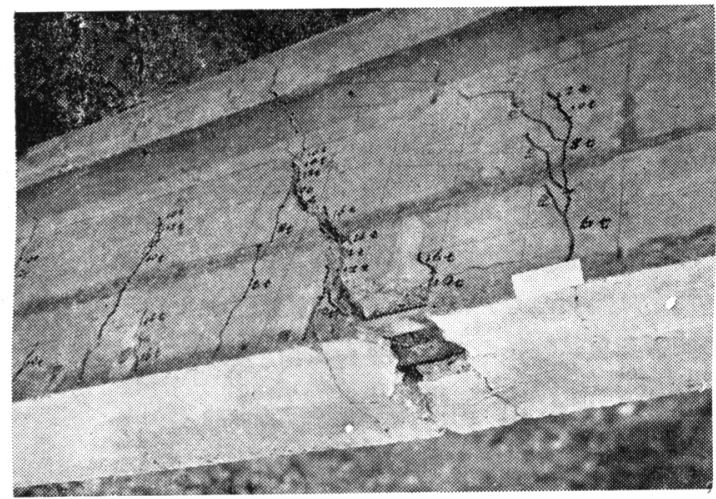

その表面にある程度のさびが生じており，このため鉄筋 の付着強度が荷重のくり返しによって低下しなかった が, No. 2 の試験ばりの丸鋼はこの試験のために特に圧 延されたもので，その表面が黒かわの状態であった。こ のため荷重のくり返しによって鉄筋の付着強度が低下 し, 、わゆる付着疲労現象を起こし, これによって鉄筋 の応力ははりの端部まで一様に大きくなって定着部破壊 が生じたのである。このことは次節以下に示す鉄筋およ びュンクリートのひずみ，ひびわれおよびたわみについ ても, No. 1 の試験ばりでは荷重のくり返しの影響がほ とんどなく, No. 2 の試験ばりでは荷重のくり返しの影 響がいちじるしいことによっても示される。これらのこ とは, 丸鋼の表面に適当なさびがあって付着疲労が防止 できれば，丸鋼を用いたはりは異形鉄筋を用いたはりよ りその疲労強度は高くなるが, 表面が平滑な丸鋼では荷 重のくり返しによって付着疲労をおこす危険性をもって いることを示すものである。鉄筋の付着強度は時間とと もに低下することも考えられるので, 丸鋼の付着疲労に ついてはその耐久性をも考慮して検討すべきことで, 丸 鋼を用いた場合には常に付着疲労に対して適当な安全率 を確保する必要がある。この $10^{6}$ 回の荷重くり返しによ る付着疲労荷重に対応する引張鉄筋の上限応力度を常用 設計方法によって求めると $2300 \mathrm{~kg} / \mathrm{cm}^{2}$ (荷重 $16 \mathrm{t}$ に 対する計算值) と $2700 \mathrm{~kg} / \mathrm{cm}^{2}$ (荷重 $19.2 \mathrm{t}$ に対する 計算值）の中間になる。したがって下限応力度 $300 \mathrm{~kg} /$ $\mathrm{cm}^{2}$ (荷重 $2 \mathrm{t}$ に対する計算值) を減じた片振幅の計算 応力度の平均值は $2200 \mathrm{~kg} / \mathrm{cm}^{2}$ 程度になる。しかし次 節以下で示すように荷重のくり返し回数とともにひず み, ひびわれ, たわみが変化し, 変形が進行するので, 疲労を考慮した場合の丸鋼の許容引張応力度に対しては 上述の值に対してかなり大きな安全率が必要と思われ る。

異形鉄筋を用いた試験ばりはすべて引張鉄筋の疲労破 断によってはりが破壊した。I型のせん断補強をした場 合にはその破断箇所はすべてスパン中央部の曲げモーメ ント最大の部分で, II 型のせん断補強をした試験ばりは
その一部はスパン中央部, 一部はせん断スパン部であ る。この破断位置はひびわれ位置とは完全には一致しな いが，一般にはひびわれに近い所で切れている。II型の 試験ばりでせん断スパン部で破壞したものは斜めひびわ れの一つが大きくなり，それと引張鉄筋との交点付近で 鉄筋が破断している。このII型の試験ばりのうちせん断 スパン部で引張鉄筋が疲労破断している試験ばりの数は 2 本で, この場合のII型のせん断補強をした試験ばり全 体に対する割合は $1 / 2$ であるが，5.でのべる比較試験を ふくめて 2 19.2 $\mathrm{t}$ の荷重段階で破壊したII型のせん断 補強の試験ばり全体について見ると，その割合は約 $3 / 7$ である。静荷重試験においては，正型のせん断補強によ る試験ばりでもすべてスパン中央の鉄筋の降伏による曲 げ引張破壊であることと比較すれば, 荷重のくり返しに 対してはせん断スパン部で破壊が生じやすいことを示し ている。これは土木学会の鉄筋コンクリート標準示方書 の規定より大幅にせん断補強鉄筋量を少なくすることは 部材の安全率を低下させる場合もあることを示すもので ある。このせん断スパン部における折曲鉄筋位置の鉄筋 応力はスパン中央部の鉄筋応力の約 $67 \%$ であるのに, この部分がスパン中央部より先に疲労破断したのは鉄筋 に引張応力とせん断応力とが二重に作用したことによる ものと思われる。

またI型のせん断補強をしたものはせん断スパンで破 壞していないことから考えて, せん断補強を十分に行な えば, せん断スパン部で破壞した No. 8, No. 9 の試験 ばりの疲労強度は表一8 に示す值より大きくなるものと 思われる。

以上に示したよらに高張力異形鉄筋を用いた試験ばり の疲労破壊は主としてその引張鉄筋の疲労破断によるも のであるので, くり返し荷重をうける部材の引張鉄筋の 許容応力度はその疲労強度を考慮して定める必要があ る。常用設計方法によって, この場合の異形鉄筋の $10^{6}$ 回の荷重くり返しによる疲労破断荷重に対する上限応力 度を求めると $2300 \mathrm{~kg} / \mathrm{cm}^{2}$ (荷重 $16 \mathrm{t}$ に対する計算値) と $2700 \mathrm{~kg} / \mathrm{cm}^{2}$ (荷重 $19.2 \mathrm{t}$ に対する計算值) の中間 になる。この平均值として $2500 \mathrm{~kg} / \mathrm{cm}^{2}$ をとり, 下限 応力度 $300 \mathrm{~kg} / \mathrm{cm}$ (荷重 $2 \mathrm{t}$ に対する計算值) を減じた 片振幅の計算応力度 $2200 \mathrm{~kg} / \mathrm{cm}^{2}$ に対して, 疲労強度 のばらつきを考慮してこれに $10 \%$ の安全率を考えれば, 現行の高張力異形鉄筋の片振幅の疲労荷重に対する許容 引張応力度の上限值は $2000 \mathrm{~kg} / \mathrm{cm}^{2}$ 程度に, $20 \%$ の安 全率を考えれば $1800 \mathrm{~kg} / \mathrm{cm}^{2}$ 程度にとるのが適当と思 われる。

このように異形鉄筋を用いた試験ばりは一般に2 $19.2 \mathrm{t}$ の荷重段階で破壊しているが，No. 7 の試験ばり は 2 16 t, 2 19.2 $\mathrm{t}$ に対してそれぞれ $10^{6}$ 回（合計で $2 \times 10^{6}$ 回) の荷重のくり返しに耐え,さらに $2 \sim 23 \mathrm{t}$ の 
$4.5 \times 10^{5}$ 回の荷重のくり返しによって, 鉄筋の疲労破断 により試験ばりが破壊した。No. 4 以下の試験ばりの高 張力異形鉄筋は No. 1 の試験ばりの丸鋼より引張強度お よび降伏点がともに高いもので, 鉄筋の表面に応力集中 がなければ No. 1 の試験ばりの丸鋼以上の疲労強度に することは可能である。そのためには必要な付着強度を 確保する範囲内で鉄筋表面の応力集中を少なくすること が必要である。No. 7 の試験ばりの異形鉄筋は縦リブ横 フシ丸型の異形鉄筋であるが，応力集中が少なくなるよ らにフシの立上り部に曲率を設けてあるもので，鉄筋の 表面形状を改善することによって疲労強度が高まること を示している。また 5. に示す No. 13, No. 14 の試験ば りの鉄筋も疲労性を考慮してその表面形状を改善したも ので, その結果は No. 7 の試験ばりと同程度の疲労強 度があることを示している。この場合の $10^{6}$ 回の荷重く り返しによる疲労破断荷重に対する上限応力度は 2700 $\mathrm{kg} / \mathrm{cm}^{2}$ と $3300 \mathrm{~kg} / \mathrm{cm}^{2}$ の中間になる。この平均值とし て $3000 \mathrm{~kg} / \mathrm{cm}^{2}$ をとり, 下限応力度 $300 \mathrm{~kg} / \mathrm{cm}^{2}$ を減じ た片振幅の計算応力度 $2700 \mathrm{~kg} / \mathrm{cm}^{2}$ に対して疲労強度 のばらつきを考慮してこれに $10 \%$ の安全率を考えれば, 片振幅の疲労荷重に対する許容引張応力度の上限值は $2400 \mathrm{~kg} / \mathrm{cm}^{2}$ 程度に，20\% の安全率をとれば $2200 \mathrm{~kg} /$ $\mathrm{cm}^{2}$ 程度になる。このように疲労性のよい, かつ前述の

写真一10 異形鉄筋の疲労破断状態 (2)

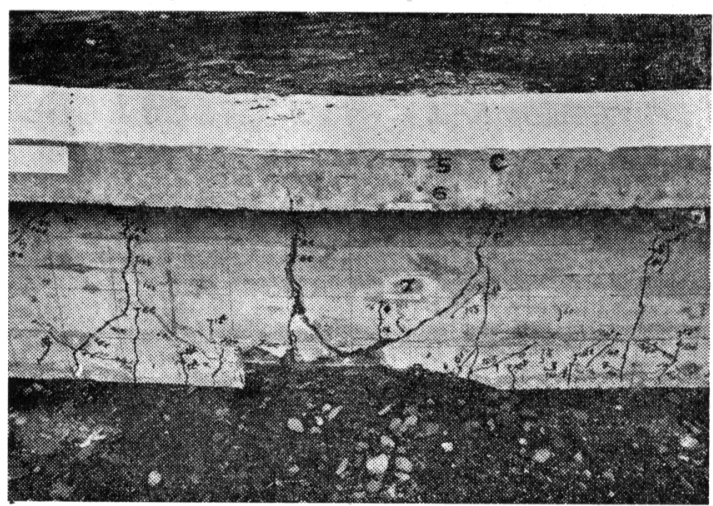

写真一11 丸鋼の疲労破断状態

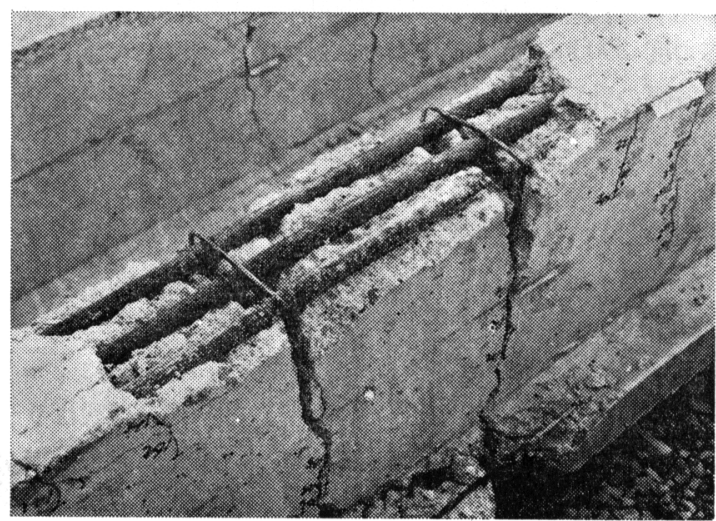

丸鋼のような付着疲労の危険性がない鉄筋が開発されれ ば，疲労に対する許容引張応力度もかなり高くすること ができるものと思われる。

写真一10 14 はこれらの試験 ばりの引張鉄筋の疲労 破断の状態を示したものである。

（2）コンクリートのひずみ

疲労荷重試験前の $0 \sim 16 \mathrm{t}$ の載荷試験， $1 \times 10^{6}$ 回の疲 労荷重試験後の 0 19.2 $\mathrm{t}$ の載荷試験，および $2 \times 10^{6}$ 回 の疲労荷重試験後の 0 2 $23 \mathrm{t}$ の載荷試験において，ワイ

写真一12 異形鉄筋の疲労破断状態 (2)

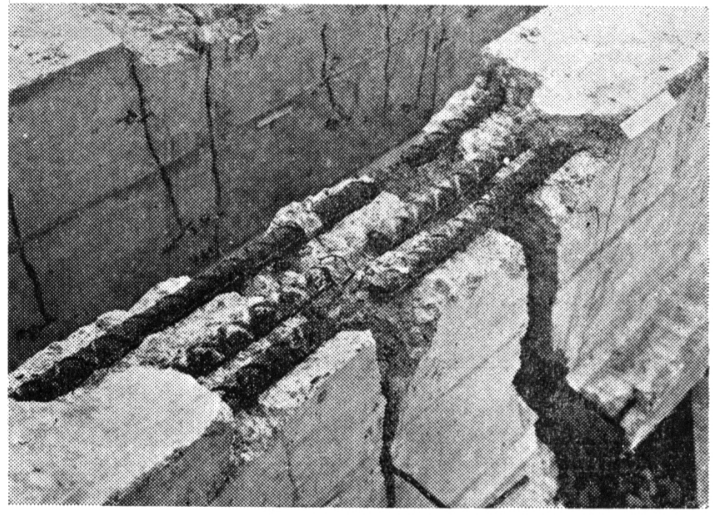

写真一13 異形鉄筋の疲労破断状態 (3)

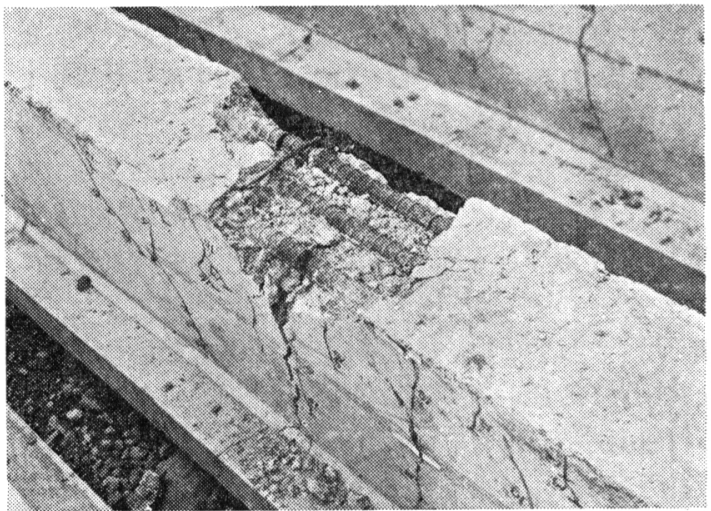

写真-14 異形鉄筋の疲労破壞状態 (4)

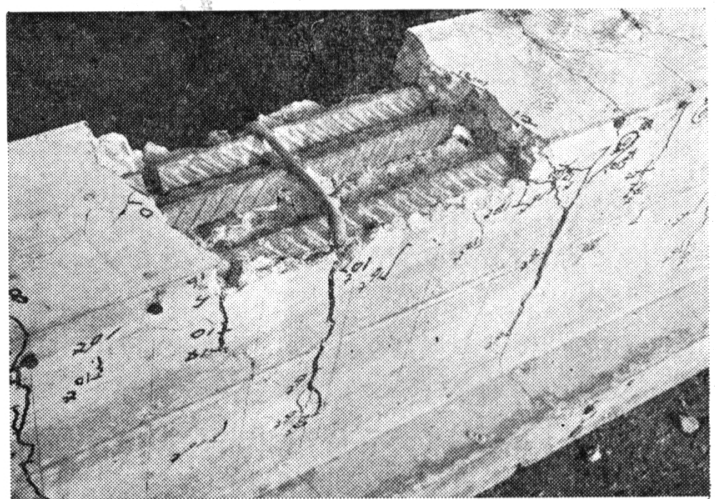


図一8 コンクリートのひずみ（疲労荷重試験 I）

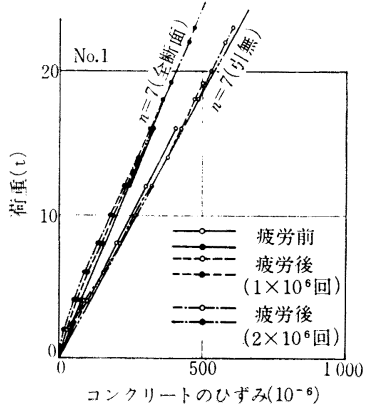

コンクリートのUずみ(10-6)
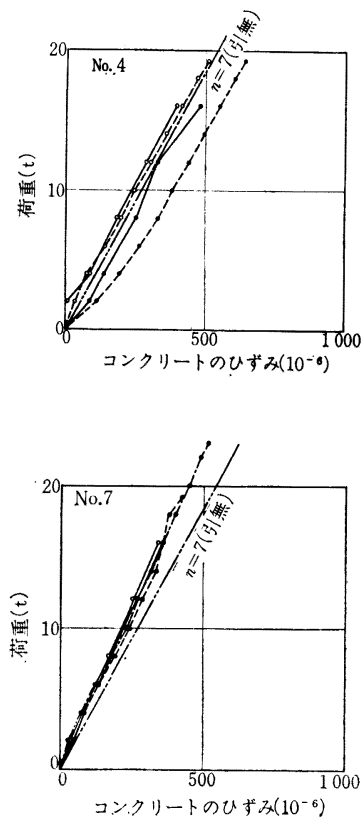

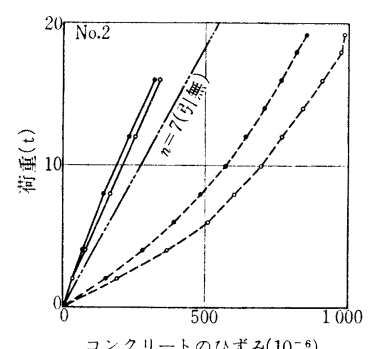

コンクリートのUずみ( $\left(10^{-6}\right)$
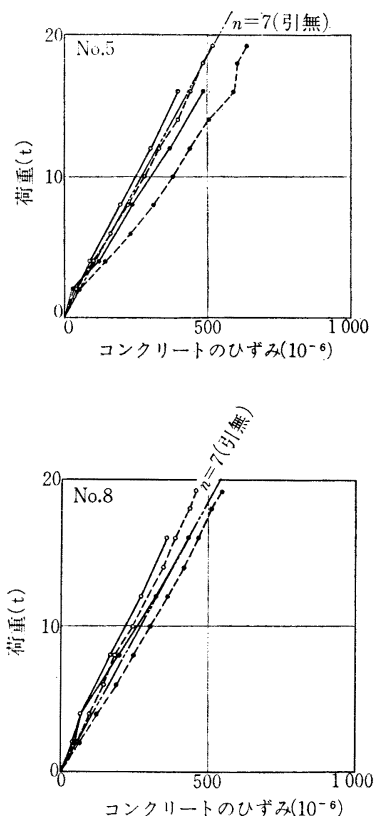
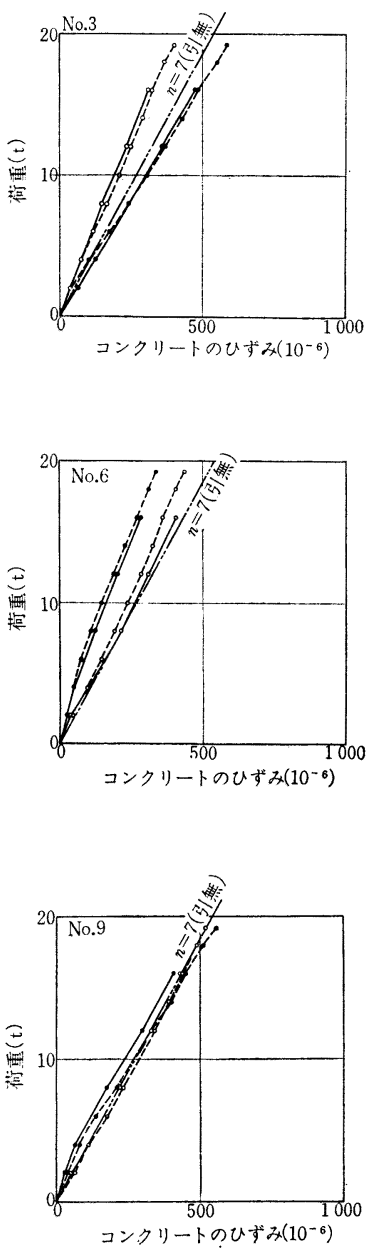

ヤ ストレィン ゲージによるコンクリート表面のひずみ 測定を行なった。図一8 は.スパン中央の圧縮フランジ側 面上部 (上面より $10 \mathrm{~mm}$ ) の測点のひずみの測定結果を 示したものである。このうち実線は疲労荷重試験前, 点 線は $10^{6}$ 回の疲労荷重試験後, 鎖線は $2 \times 10^{6}$ 回の疲労 荷重試験後における載荷試験結果で, 圧縮縁の両側にお ける 2 箇所の実測值を示したものである。図の中の 2 点 鎖線はコンクリートの引張縁を無視して $n=7$ として求 めた計算值で, 一部に全断面有効とし $n=7$ として求め た計算值を示してある。疲労荷重試験前の載荷試験は 3. の静荷重試験と同一の試験であるので, これらの結果は 一致している。疲労荷重試験後の載荷試験における荷重 とひずみとの関係は丸鋼を用いた No. 2 の試験ばりを 除いて疲労荷重試験前とほとんど同一で，コンクリート のひずみは定着部破壊した No.2の試験ばりを除いて荷 重のくり返しの影響をほとんどつけないことを示してい る。No. 2 の試験ばりは鉄筋の付着強度が荷重のくり返 しによって低下し,はりの変形が大きくなったもので,コ ンクリートのひずみは疲労荷重によって大きく影響され
図一9 コンクリートのひずみ（動的測定）
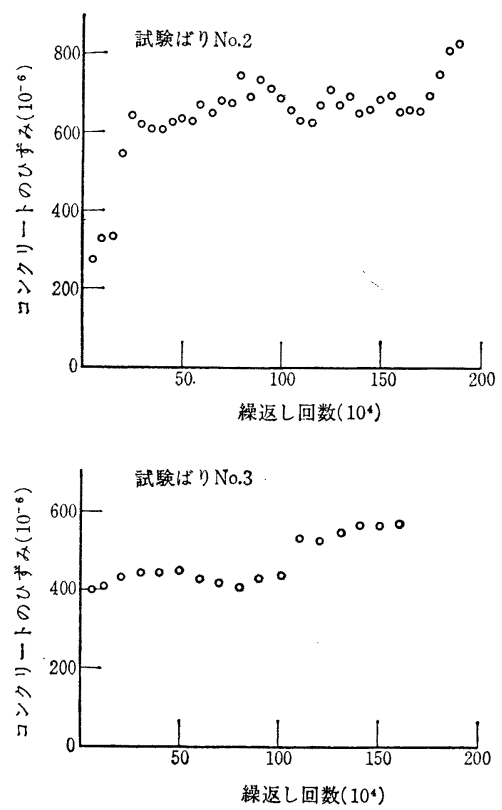
図一10 鉄筋のひずみ（疲労荷重試験 I）
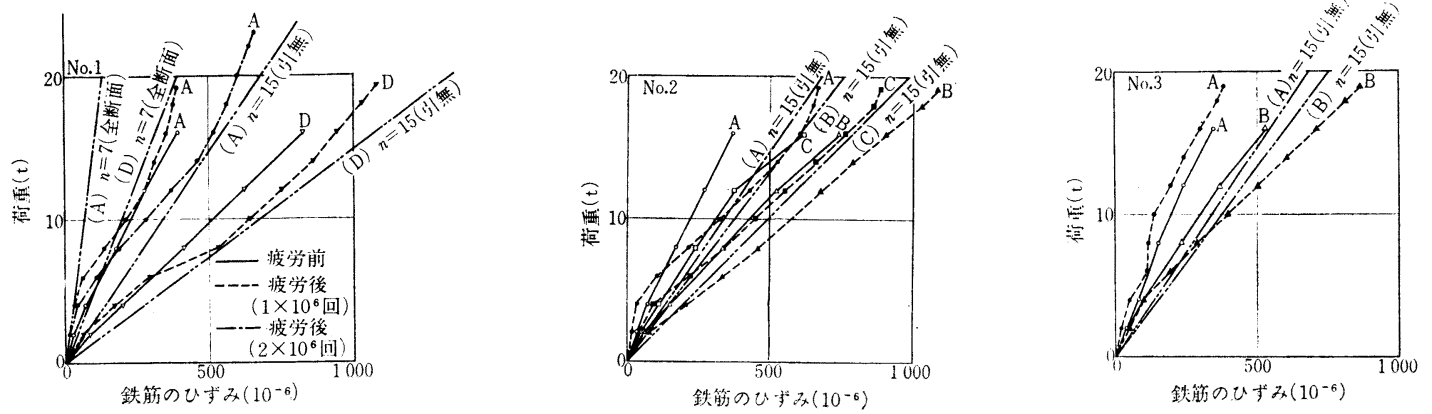
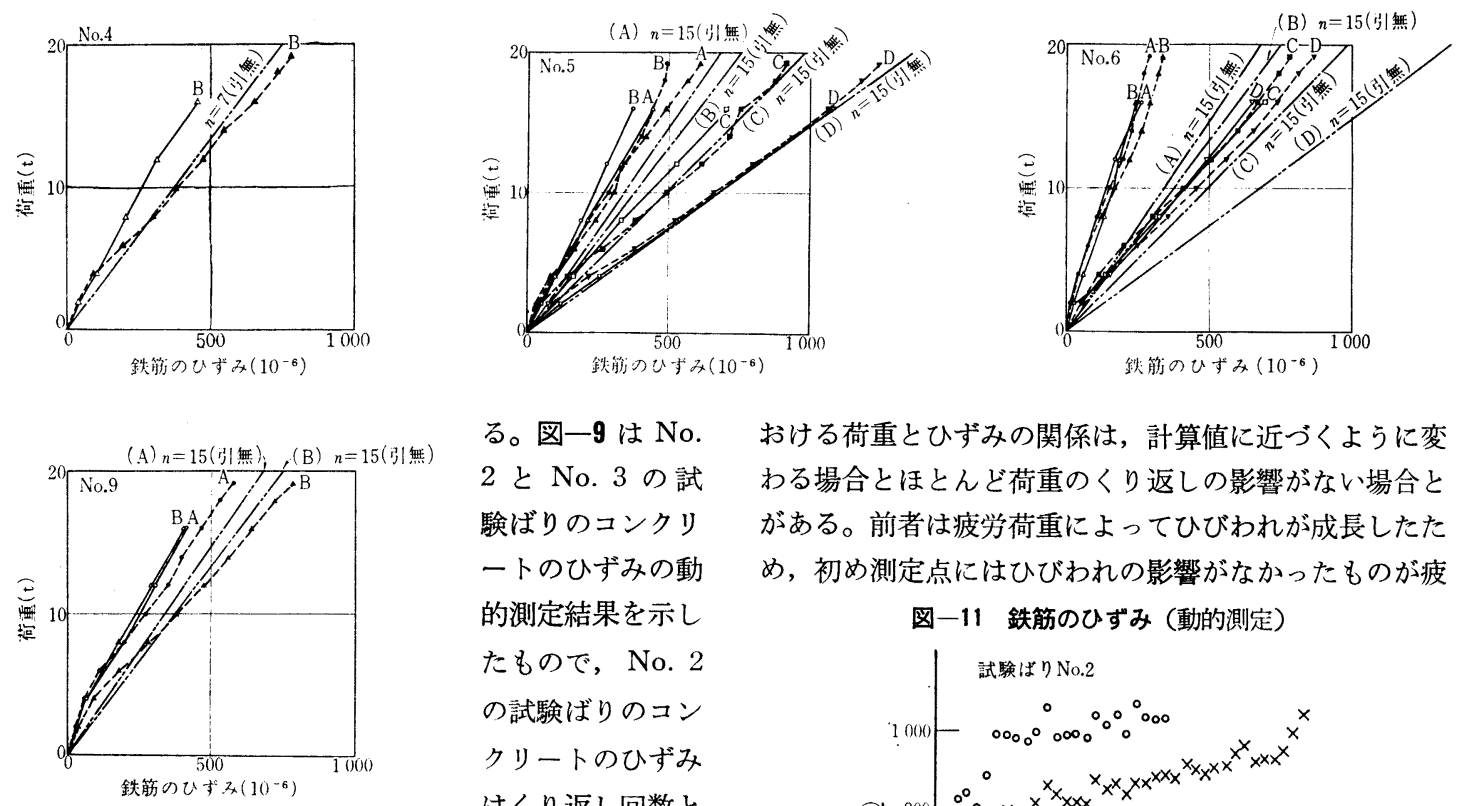

る。図一9 は No. 2 と No. 3 の試 験ばりのコンクリ ートのひずみの動 的測定結果を示し たもので, No. 2 の試験ばりのコン クリートのひずみ はくり返し回数と

ともに変化するが, 異形鉄筋を用いた No. 3 の試験ば りはひずみが比較的安定している。No. 2 以外の試験ば りのひずみの動的測定結果は No. 3 の試験ばりとほと んど同じである。

\section{(3) 鉄筋のひずみ}

鉄筋のひずみ測定の結果が疲労荷重試験後に得られな いものもあったが, 测定できたものを比較して示すと図 -10 のようになる。このうち A, B, C, D は図一1に 示す鉄筋のひずみの測定点を示すもので, 実線は疲労荷 重試験前, 点線は $10^{6}$ 回の疲労荷重試験後, 鎖線は $2 \times$ $10^{6}$ 回の疲労荷重試験後のひずみ測定結果である。困の 中の 2 点鎖線はコンクリートの引張縁を無視し $n=15$ と して求めた計算值で, 一部に全断面有効とし $n=7$ とし て求めた $\mathrm{A}$ 点および $\mathrm{D}$ 点の計算值を示してある。疲労荷 重試験前の鉄筋のひずみの実測値は前章の静荷重試験の 結果と同様に測定位置とひびわれとの関係からかなりば らついており，また一般に計算值より小さいが，最大の ものは計算値に近い值を示している。疲労荷重試験後に
おける荷重とひずみの関係は, 計算値に近ゔくように変 わる場合とほとんど荷重のくり返しの影響がない場合と がある。前者は疲労荷重によってひびわれが成長したた め, 初め測定点にはひびわれの影響がなかったものが疲 図一11 鉄筋のひずみ（動的測定）
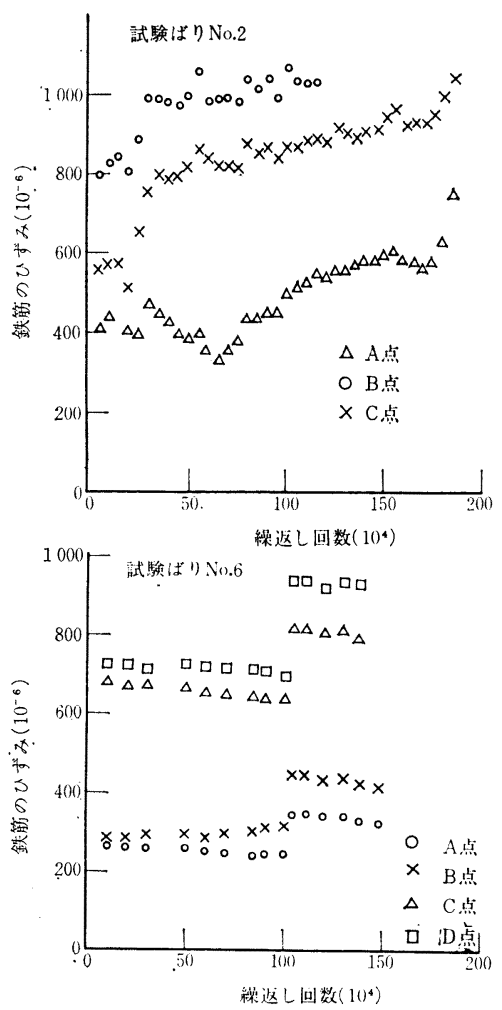
図-12 曲げひびわれ幅（疲労荷重試験 I ）
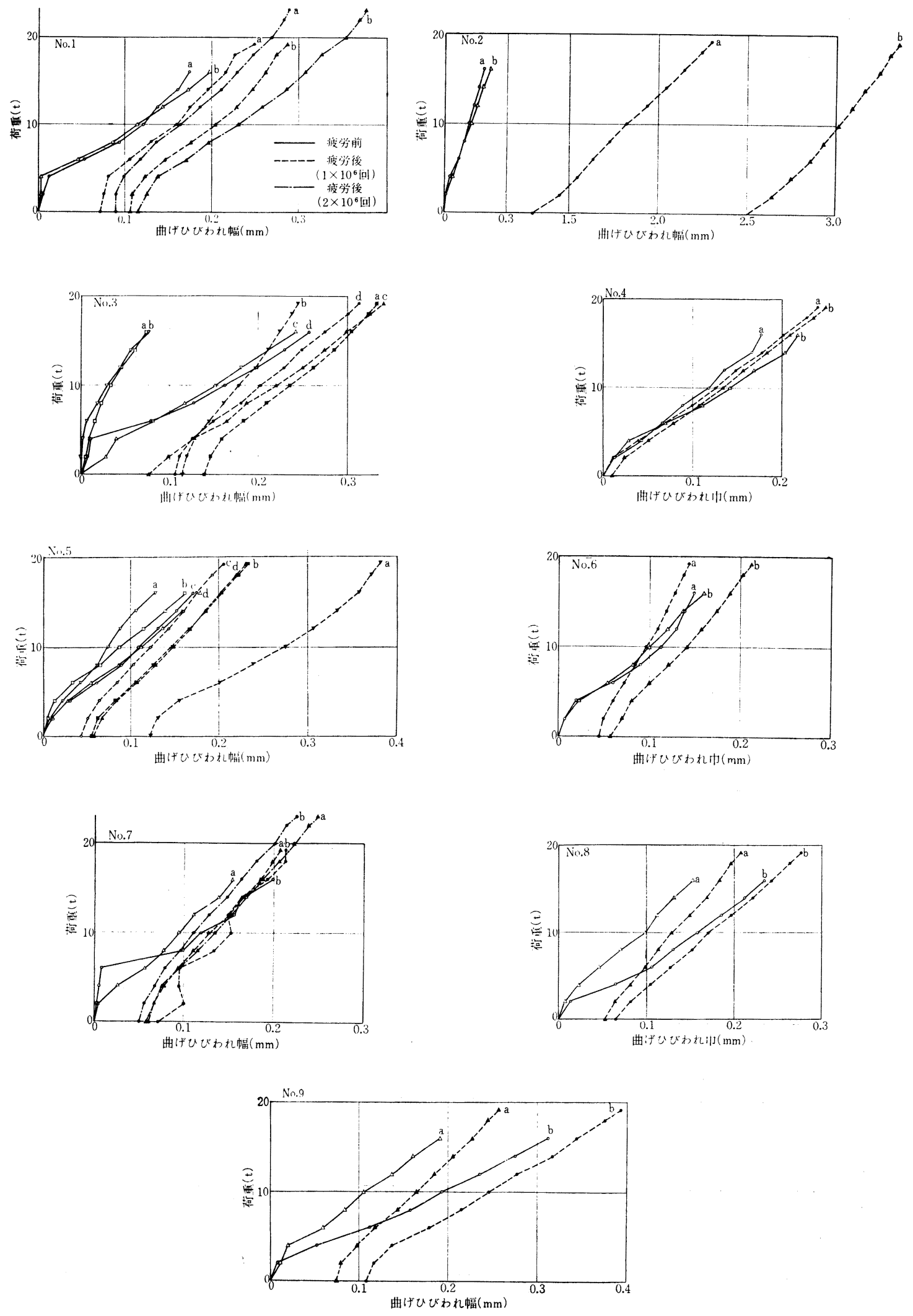
労荷重によってひびわれの影響を大きくうけるようにな ったもので, 後者は疲労荷重後においてもひびわれ変化 の影響が比較的に少ないものである。この疲労荷重後の 鉄筋のひずみは No. 2 の試験ばりを除いて前述の計算 值を大幅に上まわるものはない。No. 2 の試験ばりのB 点は疲労荷重前に抒いて計算值以上のひずみを生じて おり，疲労荷重後ではこのひずみは急激に大きくなって いる。B点はこのはりのせん断スパンにおける測定点で， $\mathrm{A}$ 点および $\mathrm{C}$ 点も疲労荷重の影響を比較的大きく受けて いる。このように No. 2 の試験ばりはせん断スパンの 引張鉄筋の応力が疲労荷重によって増大し, 鉄筋とコン クリートの付着が切れて定着部破壊を生じたものであ る。図一11 は No. 2 と No. 6 の試験ばりの鉄筋のひ ずみの動的測定結果を示したもので，No. 2 の試験ばり の鉄筋のひずみはくり返し回数とともに変化するが, No. 6 の試験ばりのひずみは比較的安定している。No. 6 以外の試験ばりのひずみの動的測定結果は No. 5 の 試験ばりとほとんど同じである。

\section{(4) ひびわれ}

疲労荷重試験前の $0 \sim 16 \mathrm{t}$ の載荷試験によって曲げひ
びわれが発生した。このスパン中央部における曲げひび われの間隔は静荷重試験の場合と同様に異形鉄筋を用い た試験ばりでは丸鋼を用いた試験ばりよりその間隔は小 さい。疲労荷重によってこのひびわれ幅は若干大きくな るが，曲げひびわれの数はほとんど増加しない。しかし 疲労荷重によってせん断スパンには新たなひびわれが斜 め方向に発生した。疲労荷重によってせん断スパン部で 破壞したはりのせん断ひびわれ幅はいちじるしく大きく なった。また荷重のくり返しによって腹部下部の鉄筋位 置に水平のひびわれも生じた。これらのひびわれの状態 は図一7および写真一8に示すようである。荷重のくり 返しによって一つのひびわれ幅が大きくなると，その隣 接するひびわれ幅の成長がとまって逆に小さくなる場合 もあるが，この曲げひびわれのうち疲労荷重前後におけ る最大のものの 2 個について, 疲労荷重試験前後のひび われ幅の変化を示すと 図一12 のようになる。これより 丸鋼を用いた No. 2 の試験ばり以外はひびわれ幅の成 長は比較的に小さく，荷重を零とした場合の残留ひびわ れも $0.1 \mathrm{~mm}$ 以下であるが, No. 2 の試験ばりのひび われ幅は約 10 倍程度大きく成長している。これは付着
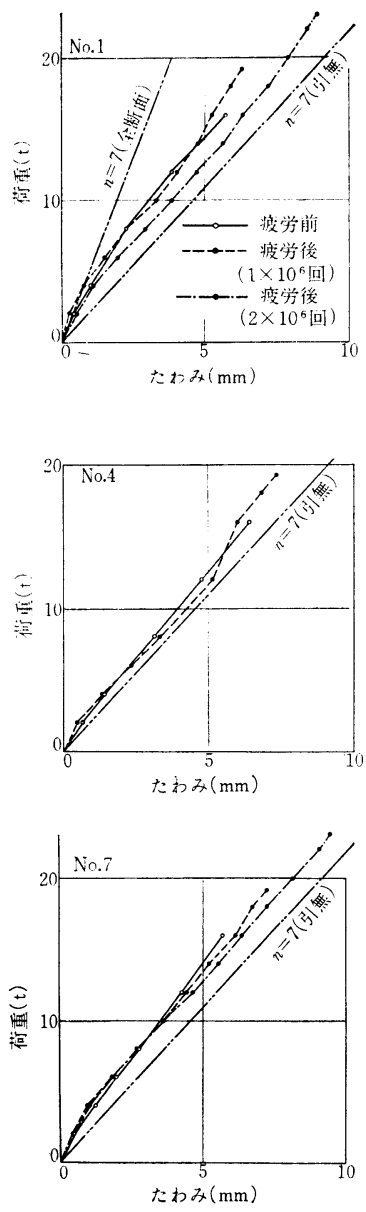

図一13 た み（疲労荷重試験 I )
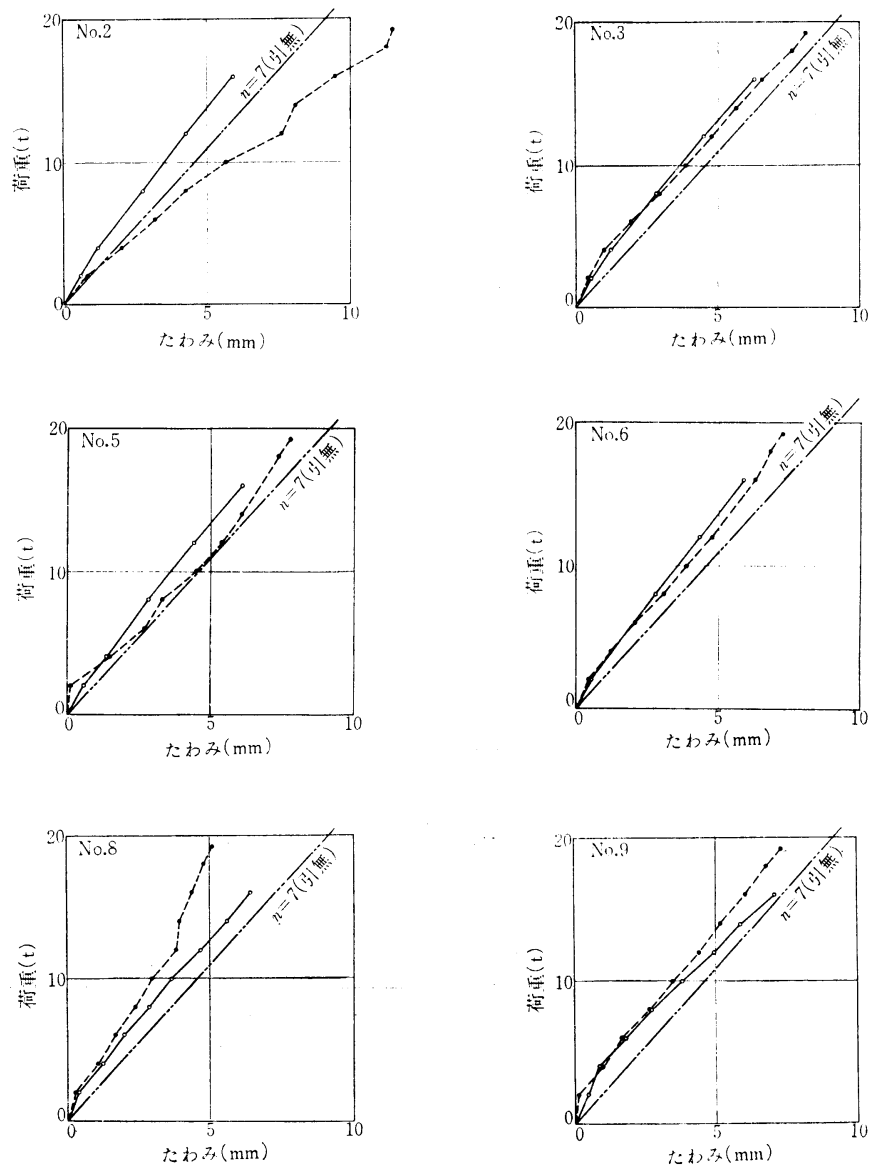
疲労したことを示している。

スパン中央部で曲げ疲労破断をした $2 \sim 3$ の試験ばり について，せん断スパンにおけるひびわれ幅の測定も行 なったが，ひびわれ幅の成長は 図一11 における No. 2 の試験ばり以外のものとほぼ同様な傾向を示し, $1 \times 10^{6}$

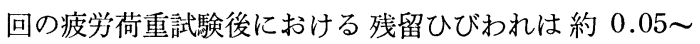
$0.1 \mathrm{~mm}$ であった。

(5) たわみ

スパン中央部の測定值より両端の支承部の測定值の平 均を減じて求めたスパン中央の実たわみについて, 前述 のひずみおよびひびわれと同様に, 疲労荷重試験前後の 測定結果を示すと 図一13 のようになる。このうち計算 值を示す 2 点鎖線はコンクリートの引張縁を無視し, コ ンクリートのヤング係数を $3.0 \times 10^{5} \mathrm{~kg} / \mathrm{cm}^{2}(n=7)$ と して求めたもので, 一部に全断面有効として求めた值を 示してある。実測值はNo. 2 の試験ばりを除いてこれ らの計算值の中間に入っている。また疲労荷重試験前後 の荷重とたわみの関係はほとんど変化がない。したがっ て No. 2 以外の試験ばりは疲労の影響がないものと考 えてよい。No. 2 の試験 ばりの疲労荷重試験後のたわ みは引張縁を無視して求めた計算值より大きく, 鉄笳の 付着疲労によって鉄筋の定着部がゆるんできたことを示 している。図-14 は No. 2 と No. 7 の試験ばりのス パン中央のたわみの動的測定結果を示したもので, No. 2 の試験ばりのたわみは荷重のくり返し回数とともに変 化するが, No. 7 の試験ばりのたわみは比較的安定して いる。No. 7 以外の試験 ばりのたわみの 動的測定結果 は No. 7 の試験ばりとほとんど同じである。
図一14 たわみ（動的測定）
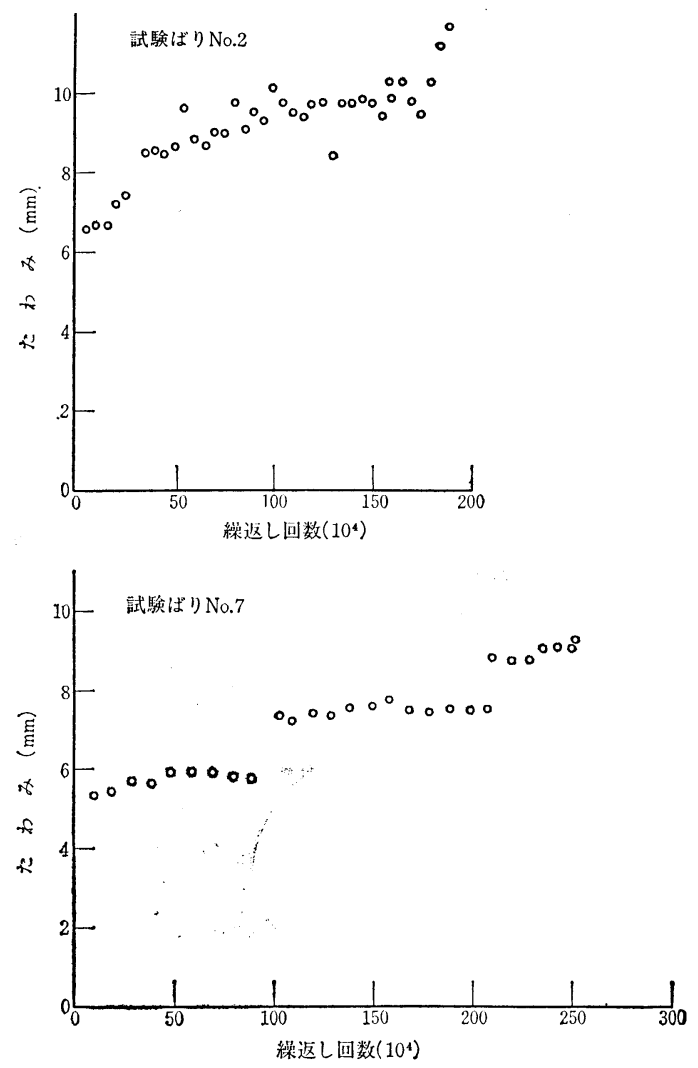

図一15 コンクリートのひずみ（疲労荷重試験 II）
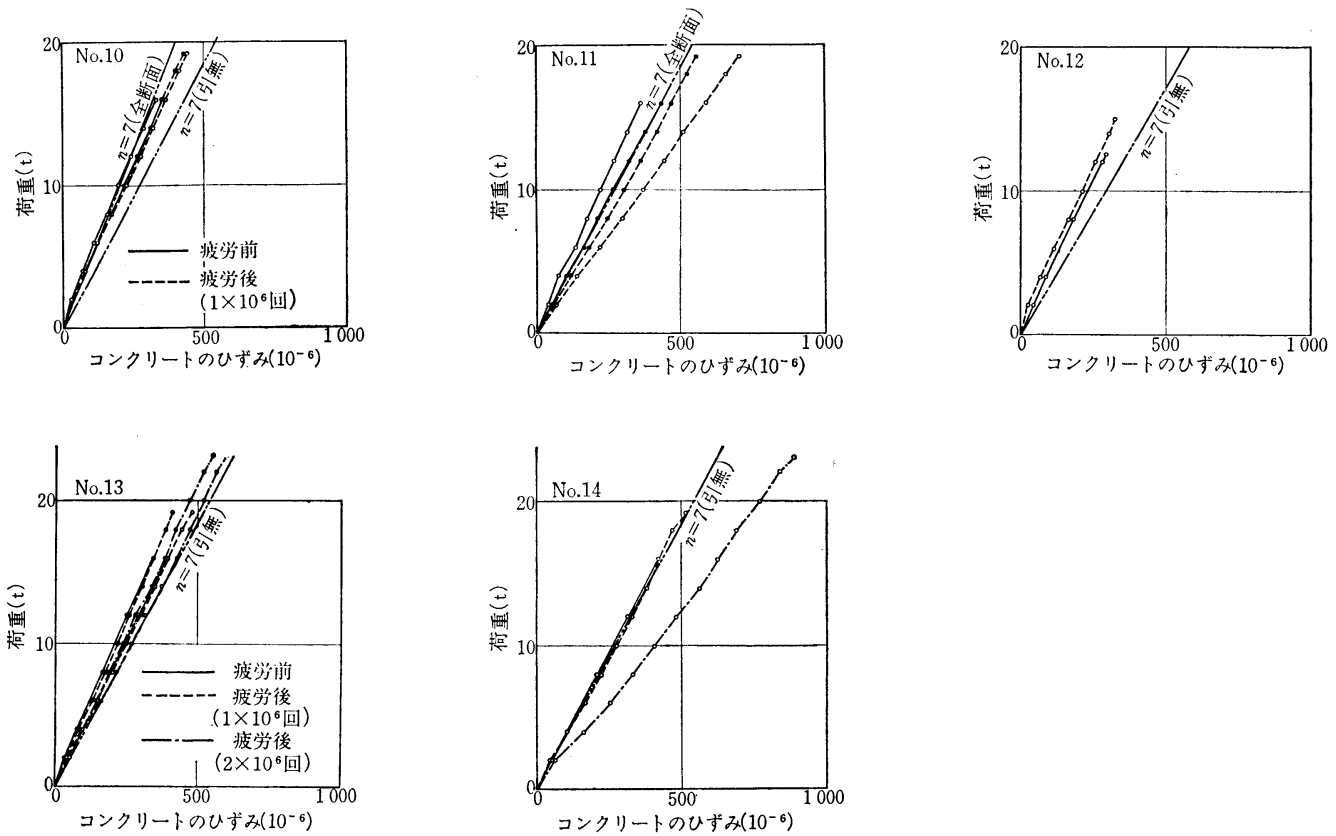


\section{5. 疲労荷重試験結果および考察（II）}

前章で丸鋼および代表的な高張力異形鉄筋を用いたは りの疲労破壊は，通常のせん断補強を行なった場合には 主として引張鉄筋の疲労破断によって生ずること，およ びこの鉄筋の破断強度は材質よりもその表面形状に大き く影響されることを示したが，この関係をさらに検討す るためメーカー一社の試験的に作られた数種の異形鉄筋 を用いて試験ばりをつくり，疲労荷重試験を行なった。 この疲労試験に用いた異形鉄筋は,フシの高さ $2.0 \mathrm{~mm}$ の斜めフシ丸型のI -1〜I-6 の 6 種で, その性質は表一 5 に，表面形状は 写真一1 に示すものである。

このほか，D-1 および D-2，E-1 および E-2 の異 形鉄筋についても試験ばりをつくり，疲労荷重試験を行 なった。これらの性質および形状も表一5, 写真一1 に 示すとおりである。これらの試験結果について考察を加 えることにする。

\section{（1）破壊荷重}

I -1〜I-6 の異形鉄筋を用いた 試験ばりの試験結果 を一括して示すと表一9のようになる。ここで試験を行 なった試験ばりは，No. 12 の試験ばりを除いて 2 16 t の荷重の $10^{6}$ 回のくり返しに耐えたが（鉄筋の計算応力 度の振幅は $300 \mathrm{~kg} / \mathrm{cm}^{2} \sim 2300 \mathrm{~kg} / \mathrm{cm}^{2}$ ), その後荷重の 上限のみを高めた 2〜19.2 $\mathrm{t}$ の荷重のくり返しによって No. 9〜No. 11 の試験 ばりは引張鉄筋が疲労破断し， 試験ばりが破壊した。No.13, No.14の試験ばりはこの $2 \sim 19.2 \mathrm{t}$ の荷重の $10^{6}$ 回（合計で $2 \times 10^{6}$ 回）のくり返 しに耐えたので, さらに荷重の上限のみを高めた 2 23 $\mathrm{t}$ の荷重のくり返しを行なったが，その荷重段階で $1 \times$ $10^{5} \sim 3 \times 10^{5}$ 回の荷重のくり返しによって引張鉄筋が疲 労破断し, 試験ばりが破壊した。No. 12 の試験ばりは 引張鉄筋に $6 \mathrm{D} \phi 16 \mathrm{~mm}$ を用いたもので, $2 \sim 12.5 \mathrm{t}$ の 荷重の $10^{6}$ 回のくり返しに耐え（鉄筋の計算応力度の振 幅は $400 \mathrm{~kg} / \mathrm{cm}^{2} \sim 2400 \mathrm{~kg} / \mathrm{cm}^{2}$ ), さらにこの荷重の上 限のみを高めた 2 15 $\mathrm{t}$ の荷重の $4 \times 10^{5}$ 回のくり返し で引張鉄筋が疲労破断し, 試験ばりが破壊した。これら の鉄筋の破断箇所は No. 11 No. 14 の試験ばりはスパ ン中央部で, No. 9, No. 10 の試験ばりはせん断スパン
部である。これらの試験ばりの破壊状態は前章に示した 異形鉄筋を用いた試験ばりと全く同一である。

No. 9 , No. 13, No. 14 の試験ばりは II 型のせん断 補強を行なったもので (図一1 参照),引張鉄筋の計算応 力度が $2000 \mathrm{~kg} / \mathrm{cm}^{2}$ のときの荷重 $(14 \mathrm{t})$ を設計荷重と し，これによる全せん断力に対してコンクリートを無視 してスターラップの応力度を $3800 \mathrm{~kg} / \mathrm{cm}^{2}$ にとって設 計したものである（折曲鉄筋の部分のスターラップの計 算応力度は約 $300 \mathrm{~kg} / \mathrm{cm}^{2}$ )。No. 10, No. 11 の試験ば りは而型のせん断補強を行なったもので, II型のスター ラップの間隔をさらに 2.4 倍にしたものである。引張鉄 筋に $6 \mathrm{D} \phi 16 \mathrm{~mm}$ を用いた No. 12 の試験ばりのスタ ーラップはIII型と同一として設計したものである。した がって引張鉄筋の計算応力度 $2000 \mathrm{~kg} / \mathrm{cm}^{2}$ のときの荷 重 $(10.4 \mathrm{t})$ による全せん断力に対してコンクリートを 無視してスターラップの応力度を求めると $6900 \mathrm{~kg} / \mathrm{cm}^{2}$ にもなっている（折曲鉄筋の部分のスターラップの計算 応力度は $1150 \mathrm{~kg} / \mathrm{cm}^{2}$ )。このII型のせん断補強を行な った試験ばりのうちせん断スパン部で引張鉄筋が疲労破 断しているのは 1 本で全体の $1 / 3$ であるが, 前章に示し た試験結果をふくめて 2 19.2 t の荷重段階で破壊した II型のせん断補強の試験ばり全体についても, せん断ス パン部で引張鉄筋が疲労破断している割合は全体の $3 / 7$ である。またIII型，IV型の試験ばりのうちせん断スパン 部で疲労破断しているものも全体の $3 / 7$ である。前章で 示したようにI型のせん断補強したものはせん断スパン 部で引張鉄筋が破断してないことを考えれば，土木学会 鉄筋コンクリート標準示方書の規定よりせん断補強を減 ずることは危険なことではあるが，極端にせん断補強が 少なくなっても，この場合のようにせん断スパン部で破 壊が生ずる割合はそれほど増大していない。

鉄筋の種類別に試験結果を考察する。No. 10〜No. 12 の 3 本の試験ばりに用いた鉄筋はフシの立上り部分 の形状はほぼ同一で，フシの立上り部分にフシの高さの $0.75 \sim 1.0$ 倍以下の半径の曲率がつけてある。このうち No. 11 , No. 12 の異形鉄筋は SD 50 相当の降伏点お よび引張強度を有するもので, No. 12 は鉄筋の直径が $16 \mathrm{~mm}$ で他のものより小さいものである。No. 9, No.

表一9 疲労荷重試験による破壊荷重（II）

\begin{tabular}{|c|c|c|c|c|c|c|c|c|c|}
\hline \multirow[b]{2}{*}{$\begin{array}{c}\text { 試験ばり } \\
\text { No. }\end{array}$} & \multirow[b]{2}{*}{ 鉄筋の種類 } & \multirow{2}{*}{$\begin{array}{c}\text { 材令 } 28 \text { 日に } \\
\text { おけるコンク } \\
\text { リートの強度 } \\
\left(\mathrm{kg} / \mathrm{cm}^{2}\right)\end{array}$} & \multirow[b]{2}{*}{$\begin{array}{l}\text { せん断 } \\
\text { 補 強 }\end{array}$} & \multirow[b]{2}{*}{ 引張鉄筋 } & \multicolumn{3}{|c|}{ くり返 ᄂ 回数 $\left(10^{4}\right)$} & \multirow[b]{2}{*}{ 破 } & \multirow[b]{2}{*}{ 状 } \\
\hline & & & & & $\begin{array}{c}2 \sim 16 t \\
(2 \sim 12.5)^{*} \\
(1)\end{array}$ & $\begin{array}{c}2 \sim 19.2 \mathrm{t} \\
(2 \sim 15)^{*} \\
(2)\end{array}$ & $\begin{array}{c}2 \sim 23 \mathrm{t} \\
(3)\end{array}$ & & \\
\hline 9 & $I-4$ & 370 & II & $3-\mathrm{D} \phi 25$ & 100 & $129(29)^{* *}$ & - & ヒん盺ひびわれより & $1 / 4$ 点の鉄筇破断 \\
\hline 10 & $I-1$ & 380 & III & $3-\mathrm{D} \phi 25$ & 101 & $105(4)$ & - & " & \\
\hline 11 & $I-2$ & 360 & III & $3-\mathrm{D} \phi 25$ & 100 & $106(6)$ & - & 中央の鉄筋破断 & \\
\hline 12 & $I-3$ & 380 & IV & $6-\mathrm{D} \phi 16$ & 101 & $138(37)$ & - & $"$ & \\
\hline 13 & $I-5$ & 390 & II & $3-\mathrm{D} \phi 25$ & 104 & $201(97)$ & $228(27)^{* * *}$ & $"$ & \\
\hline 14 & $I-6$ & 380 & II & $3-\mathrm{D} \phi 25$ & 102 & $200(98)$ & $210(10)$ & $\leadsto$ & \\
\hline
\end{tabular}

*（）内は No. 12 のはりに対する荷重を示す。 **（）内は（2）-（1）を示す。 ***（）内は（3)一（2）を示す。 
13, No. 14 の 3 本の試験ばりはフシの立上り部分の曲 率の大きいもので, No. 9 の試験 ばりの異形鉄筋 I-4 はフシの高さの 1.5 倍の半径の曲率を, No. 13 の試験 ばりの異形鉄筋 I-5 はフシの高さの 4.5 倍の半径の曲 率を, No. 14 の試験ばりの異形鉄筋 I -6 はフシの高さ の 7.5 倍の半径の曲率を, それぞれフシの立上り部につ けて応力集中を緩和している。また I-6 の異形鉄筋は リブとフシとの縁を切って，この点の応力集中をさけ ている。これらの試験結果は 表一-9 に示すとおりであ る。No. 9, No. 10 の試験ばりはせん断スパンで引張 鉄筋が疲労破断し，他のものはすべてスパン中央部で引 張鉄筋が疲労破断しているが，前章に执いてのべたよう に，せん断スパン部で破断した場合には鉄筋に引張応力 とせん断応力とが作用し，その疲労強度は若干低下する ものと考えられるので，十分にせん断補強を行なってス パン中央部で破断が生ずるようにすれば No. 9, No. 10 の試験ばりの荷重のくり返し 回数は若干大きくなる ものと考えられる。したがってこの試験結果は異形鉄筋 I-1〜 I-3 を用いた No. 10〜No. 12 の試験ばりにつ いてはその疲労強度はほとんど差がなく, 異形鉄筋 I -4 を用いた No. 9 の試験ばりの疲労強度はわずかに大き く，異形鉄筋 I-5，I-6 を用いた No. 13，No. 14 の 試験ばりの疲労強度はさらに大きいことを示している。 このように異形鉄筋の疲労強度はその降伏点および引張

写查-15 異形鉄筋の疲労破断状態 (5)

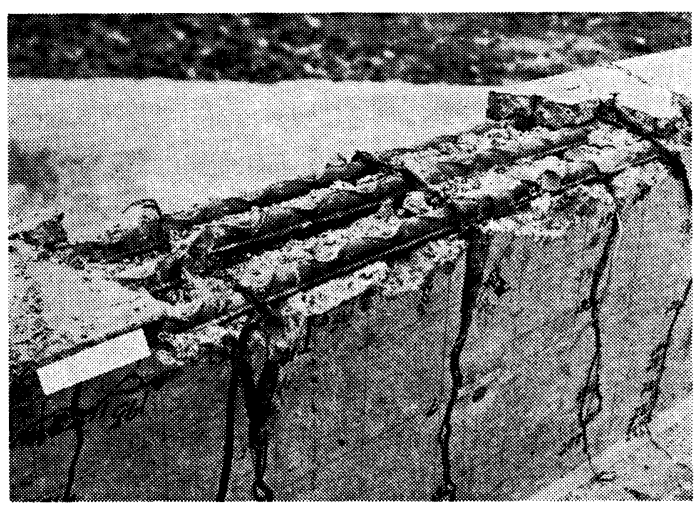

強度に関係なく，主として表面形状によって定まるもの と思われる。

このほか，D-1 および D-2, E-1 および E-2 の異 形鉄筋についてもその疲労性状を比較するため, 試験ば りをつくって疲学試験を行なったが，この結果も異形鉄 筋の疲労強度はその材質による強度よりも表面形状によ って定まることを示している。すなわち，D-1 および D-2 は同一の表面形状および材質のフシの高さ 1.75 $\mathrm{mm}$ の斜めフシ丸型の 異形鉄筋で，D-1 はフシの立上 り部にフシの高さの 2 倍の半径の曲率をつけたもの, D-2 はその曲率のないものである。D-1 の異形鉄筋に よる試験ばりは表一8の No. 4 の試験ばりの結果のよ らに2 16t の $10^{6}$ 回以上の荷重のくり返しに耐えた が，D-2 の異形鉄筋による試験 ばりは $2 \sim 16 \mathrm{t}$ の荷重 の $3 \sim 4 \times 10^{5}$ 回のくり返しでスパン中央の引張鉄筋が疲 労破断し，試験ばりが破壊した。また E-1 および E-2 も同一の材質の三角断面の異形鉄筋で, E-1 はフシの 高さ $1.5 \mathrm{~mm}$ の斜めフシ型で, そのフシの立上り部にフ シの高さの 1.3 倍の半径の曲率をつけたもの, E-2 は フシの高さ $2.0 \mathrm{~mm}$ の直角フシ型で, そのフシの立上り 部に曲率のないものである。 $\mathrm{E}-1$ の異形鉄筋を用いた 試験ばりは表一8の No. 5 試験ばりの結果のように $2 \sim 16 \mathrm{t}$ の $10^{6}$ 回以上の荷重のくり返しに耐えたが，E2 の異形鉄筋を用いた試験ばりは $2 \sim 16 \mathrm{t}$ の 5 〜 $6 \times 10^{5}$

写真一16 異形鉄筋の疲労破断状態 (6)

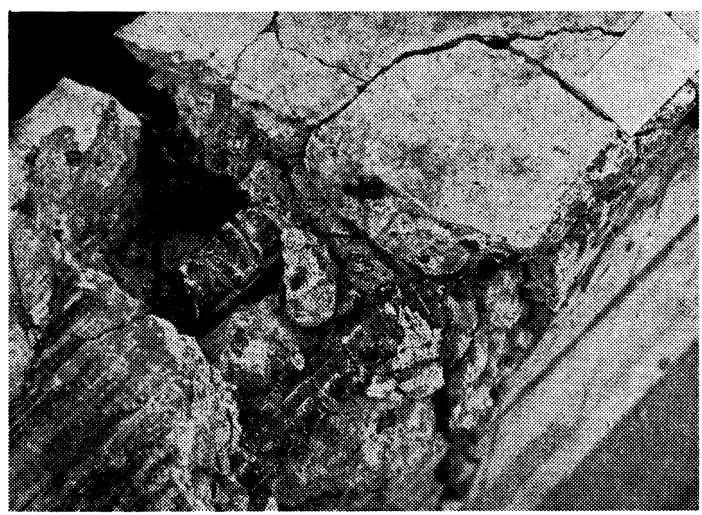

図一16 鉄筋のひずみ（疲労荷重試験 II）

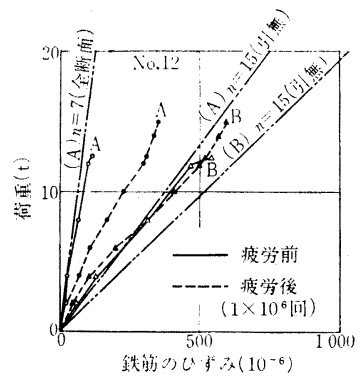

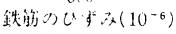

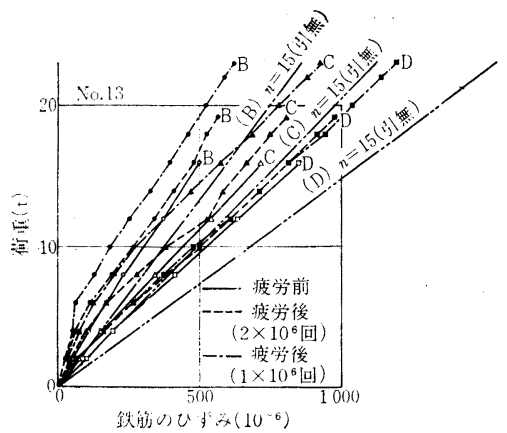

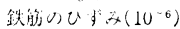

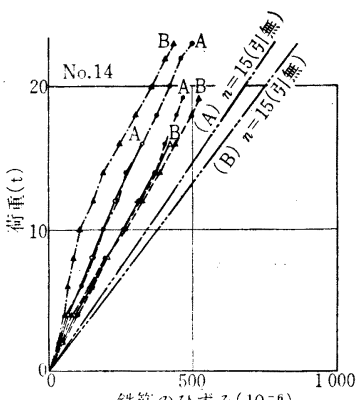

鐩筋の)过み(10-6) 
回の荷重のくり返しでスパン中央の引張鉄筋が疲労破断 し, 試験ばりが破壊した。写真一15, 16 はこれらの引 張鉄筋の破断状態を示したものである。

\section{（2）コンクリートのひずみ}

スパン中央の圧縮フランジ側面上部のワイヤ ストレ ィン ダージによるコンクリートのひずみ測定結果を, 疲労荷重試験前後について比較して示すと図一15 のよ うになる。この結果は No. 11, No. 14 の試験ばりに 若干疲労の影響が見られるが, 図一8の No. 2 の試験 ばりのような大きな変化はない。しかし，No.14の試 験ばりは次節以下に示す曲げひびわれ，たわみ等につい ても疲労荷重の影響が見られるので，鉄筋の表面形状を I-6 の異形鉄筋のよ5に極端に丸鋼に近ずけた場合に は付着疲労について検討することが必要になってくる。

\section{（3）鉄筋のひずみ}

疲労荷重試験後にひずみ測定ができたものについて, 疲労荷重試験前後のひずみ測定結果を比較して示すと図 -16 のよらになる。この結果も前章の結果と同様に, 測定位置とひびわれとの関係からかなりばらついている が, 実測值は一般に引張縁を無視して求めた計算值以下 で, 最大のものは計算值に近い值になっている。

\section{(4) ひびわれ}

曲げひびわれについても，前章に示した異形鉄筋を用 いた試験ばりの結果と一致している。図一17 はひびわ

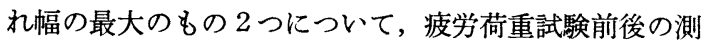
定結果を比較して示したもので, 荷重のくり返しによっ て No. 14 の試験ばりを除いて $0.05 \sim 0.1 \mathrm{~mm}$ 程度の 残留ひびわれが生じている。No. 14 は表面形状が丸鋼 に近いもので, 疲労荷重によってひびわれ幅が漸増し， $2 \times 10^{6}$ 回後の荷重のくり返しによって約 $0.2 \mathrm{~mm}$ の残 留ひびわれが生じている。これは荷重のくり返しによっ てわずかではあるが鉄筋の付着疲労が生じたことを示し ている。

\section{（5）たわみ}

スパン中央のたわみの測定値より両端の支承部のたわ みの測定值の平均を減じて求めたスパン中央の実たわみ について, 疲労荷重試験前後を測定結果を比較して示す と図一18 のようになる。この結果はコンクリートのひ ずみ測定結果の傾向と一致し, No. 11 と No. 14 の試 験ばりに疲労荷重の影響が認められ, 特に No. 14 の試 験ばりでは荷重のくり返し回数とともにたわみは漸増し ている。

\section{6. 結 論}

この試験結果は，鉄筋コンクリートばりの曲げ性状お よび疲労性状がかなり複雑であることを示している。試 験ばりの数が少ないので, この試験結果のみから一般的 な結論を導くことは困難であるが，丸鋼および各種の異
図一17曲げひびわれ（疲学荷重試験 II）
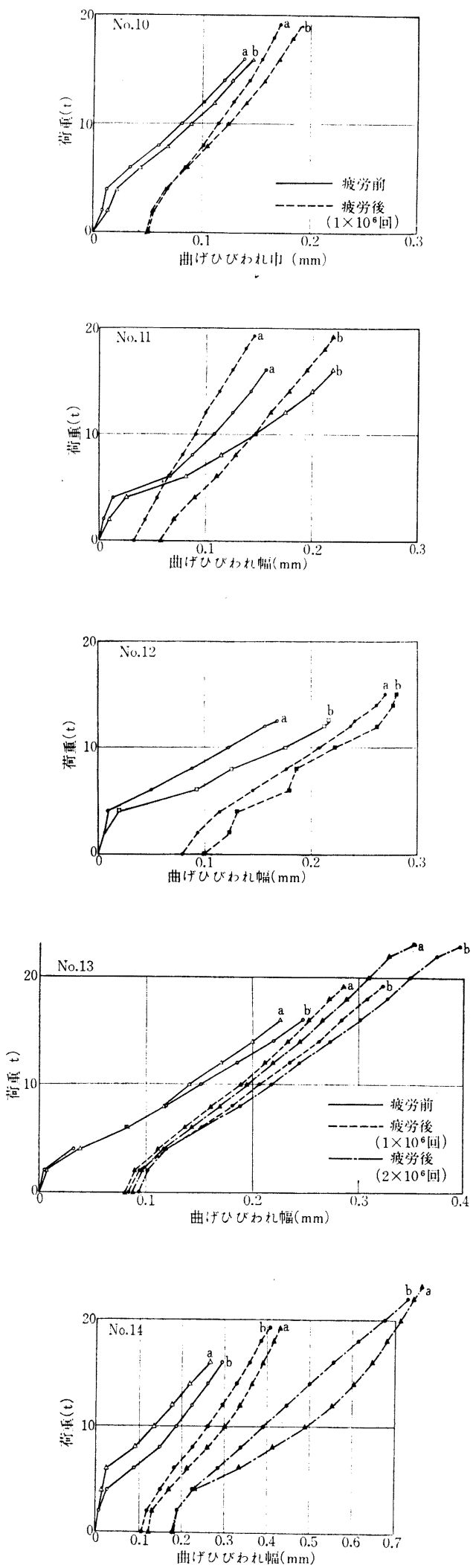
図一18たわみ（疲学荷重試験 II）
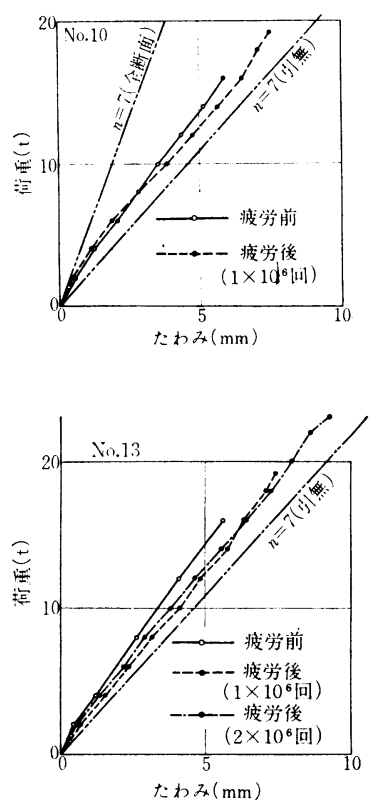
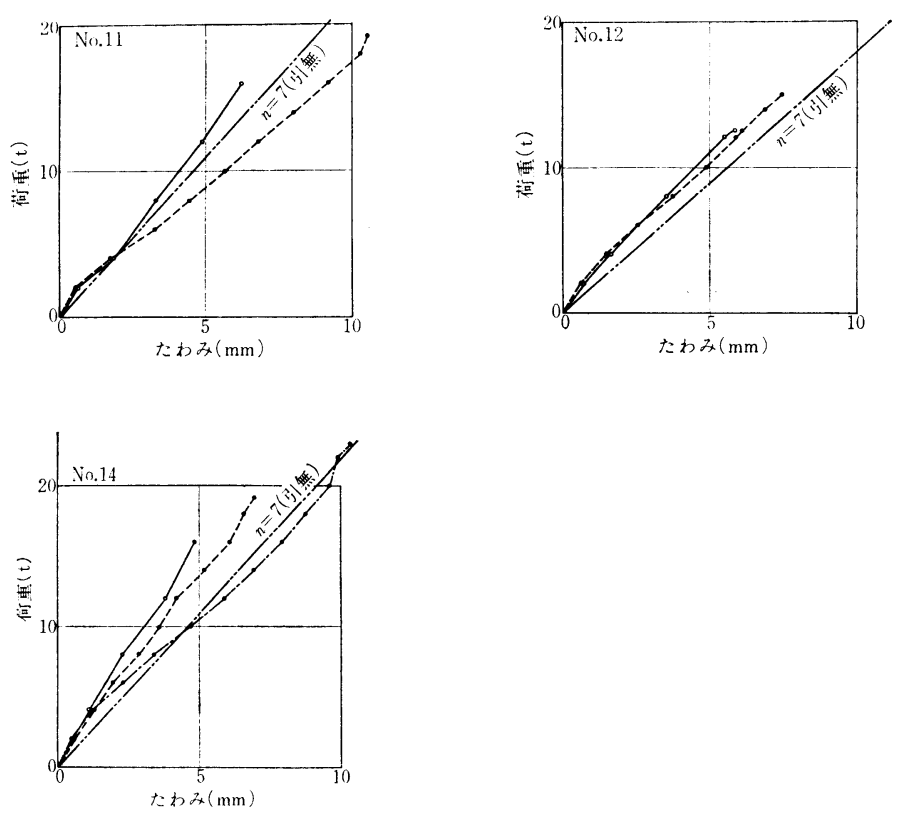

形鉄筋を用いて製作した大型T形ばりの静荷重および疲 労荷重による曲げ試験の結果より，その曲げ性状および 疲労性状について認められたことを述べるとつぎのよう になる。

（1）異形鉄筋を用いたはりの疲労試験による曲げ破 壊はすべて引張鉄筋の疲労破断によるものである。土木 建築両方面に広く用いられている一般の異形鉄筋を用い たはりの破壊時における引張鉄筋の片振幅の計算応力度 の上限值は, $10^{6}$ 回程度の荷重くり返しに対して約 2200 $\mathrm{kg} / \mathrm{cm}^{2}$ 程度であるが，特に疲労性を考慮して製作され た鉄筋では上記の上限值は約 $2700 \mathrm{~kg} / \mathrm{cm}^{2}$ 程度になっ ている。

（2）丸鋼を用いたはりの疲労試験による曲げ破壊は 引張鉄笳の疲労破断のほかに定着部破壊をおこしたもの があり，付着疲労の危険性があることを示している。こ の場合の引張鉄筋の热幅応力度の上限值は上記の普通の 異形鉄筋の上限值とほぼ一致しているが, 疲労荷重によ って変形が進行するので, 計算に用いる許容引張応力度 に対しては異形鉄筋の場合より大きな安全率が必要であ る。

（3）異形鉄筋を用いたはりの疲労試験においては, コンクリートのひずみ, 鉄筋のひずみ, ひびわれ，たわ み等は疲労荷重の影響をほとんどうけないが, 定着部破 壊を起こした丸鋼を用いた場合には疲労荷重によってひ ずみおよび変形がかなり増大する傾向が認められた。

（4）静試験による曲げ破壊はすべて引張鉄筋の降伏 による曲げ引張破壊で, この場合の降伏荷重は Whitney の極限強度の計算式および鉄筋の応力度にその降伏点を
代入して常用設計方法より求めた極限強度の計算式によ る值に比較的よく一致し, かつその結果は一般に安全側 にある。

（5）静荷重による圧縮フランジのコンクリートのひ ずみの実測值に対しては, $n=7$ (コンクリートのヤング 係数を $\left.3 \times 10^{5} \mathrm{~kg} / \mathrm{cm}^{2}\right)$ としコンクリートの引張縁を無 視して求めた值が比較的安全側の結果を与えている。引 張鉄筋のひずみの実測值はその測定位置とひびわれとの 相対位置関係からかなりばらついているが，変形が大き くなると実測值の最大のものは常用設計方法 $(\boldsymbol{n}=15)$ より求めた計算値とほぼ一致してくる。はりの実たわみ はひびわれ発生前には全断面有効として求めた值に近 く,ひびわれ発生後は引張縁を無視して求めた值にほぼ 一致している。

丸鋼を用いたはりのひびわれ幅は異形鉄筋を用いたは りのひびわれ幅より大きく，その割合はほぼ $1.1 \sim 1.3$ の範囲にある。

(6) 引張鉄笳の計算応力度 $2000 \mathrm{~kg} / \mathrm{cm}^{2}$ のときの 荷重を設計荷重とし, その全せん断力に対して土木学会 制定鉄筋コンクリート標準示方書の規定にしたがってせ ん断補強をしたものは静試験では例外なく曲げ引張破壊 を起したが, そのスターラップ量を約 $1 / 2$ にしたもので もせん断破壊が曲げ破壊に先行するものはなかった。疲 労試験においては上記の所要のせん断補強をしたはりで はスパン中央部で引張鉄筋が疲労破断を起こしている が，スターラップ量を $1 / 2$ にした試験ばりはその $3 / 7$ が せん断スパン部で引張鉄筋が疲労破断し, この場合の疲 労強度は若干小さくなっている。これはせん断補強鉄筋 
量を現行の規定量より少なくすることは部材の安全度を 低下させる場合もあることを示すものである。

\section{参 考 文献}

1）丸安隆和・吉谷 豊・小林一輔 : 冷間ねじり鉄筋の疲労 試験結果について, コンクリート・ライブラリー第 2 号, 昭和 37 年 12 月

2）河野通之 - 富田勝信 - 小松原政次 - 渡辺信一 - 小寺重郎： 異形鉄筋の疲れ強度に関する研究, コンクリート・ライ ブラリー第 2 号

3）中山紀男 : 異形鉄筋を用いた鉄筋コンクリートはりの疲 労について, セメント技術年報, 昭和 38 年

4）横道英雄・太田利隆・西堀忠信 : 鉄筋コンクリートけた
の曲げ疲労に関する実験的研究，セメント技術年報，昭 和 38 年

5）横道英雄・藤田嘉夫・小谷一三・西堀忠信 : 鉄筋コンク リートはりの疲労に関する実験的研究，セメント技術年 報, 昭和 39 年

6) Chang, T.S. \& Kesler, C.E. : Static and Fatique Strength in Shear of Beams with Tensile Reinforcement, Journal of ACI, Jun. 1958

7) Chang, T.S. \& Kesler, C.E. : Fatique Behavior of Reinforced Concrete Beams, Journal of ACI, Aug. 1958

8) Roš, M; Bericht Nr. 162 der EMPA, Zürich 1950

(1965.4.8 - 受付)

\section{論文集への討議について}

本号登載の全論文に対して討議を受付けております。討議をされる方は下記の要項をご参照 の上, 昭和 41 年 4 月 20 日までに論文集編集委員会あてご提出下さい。

記

1. 討議は論文集掲載全論文を対象とします。

2. 討議の受付は論文集揭載後 6 力月以内とします。

3. 討議原稿を提出するときは学会原稿用紙に必要事項を記入のらえ論文集編集委員会あてご提出下さい。

4. 討議原稿の取扱いは論文集編集委員会にご一任下さい。

5. 討議に関する問合せは論文集編集委員会へご連絡下さい。

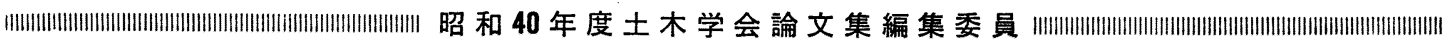

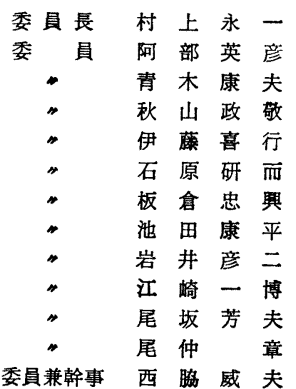

\begin{tabular}{|c|c|c|c|}
\hline 副委員長 & 粟 津 & 清 & 蔵 \\
\hline 委 & 大 橋 & 昭 & 光 \\
\hline$"$ & 大 月 & 隆 & \pm \\
\hline$"$ & 神 田 & 徳 & 自 \\
\hline$"$ & 角 田 & 直 & 行 \\
\hline$"$ & 工 藤 & 和 & 夫 \\
\hline " & 小 林 & - & 輯 \\
\hline$"$ & 佐々木 & 道 & 夫 \\
\hline$"$ & 佐 武 & 正 & A \\
\hline$"$ & 沢 口 & 昌 & 杭 \\
\hline " & 白 石 & 成 & 人 \\
\hline$"$ & 鈴 木 & 慶 & \\
\hline
\end{tabular}

委"員
"
"
"
"
"
"

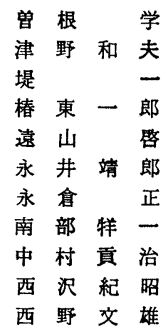

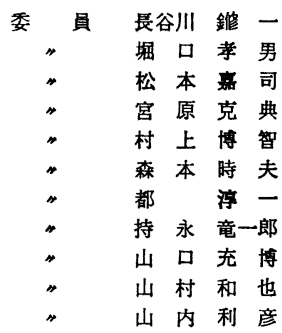

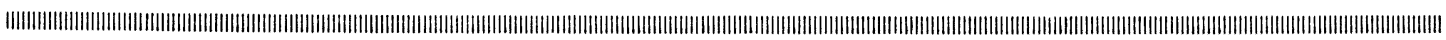

昭和 40 年 10 月 15 日印刷 昭和 40 年 10 月 20 日発行

\section{土木学会論文集 第 122 号}

定価 150 円 (广 20 円)

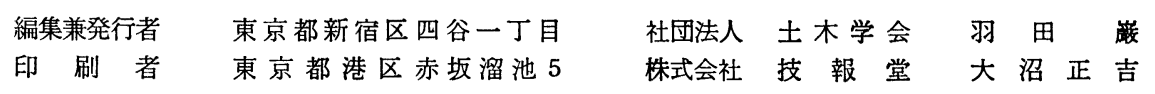

発行所篟界 土 木 学会振替東京 16828 番 東京都新宿郵便局区内 新 宿 区四谷一丁目電話 (351) 代表 5138 番 